НАЦИОНАЛЬНЫЙ ИССЛЕДОВАТЕЛЬСКИЙ ИНСТИТУТ МИРОВОЙ ЭКОНОМИКИ И МЕЖДУНАРОДНЫХ ОТНОШЕНИЙ имени Е.М.ПРИМАКОВА

РОССИЙСКОЙ АКАДЕМИИ НАУК

\title{
СОВРЕМЕННАЯ ТУРЦИЯ:
}

\section{ТРЕНДЫ РАЗВИТИЯ И ЗНАЧЕНИЕ ДЛЯ РОССИИ}

\author{
Под редакцией \\ И.Я. Кобринской, \\ Л.С. Вартазаровой, \\ С.В. Уткина
}

Москва

ИМЭМО РАН

2019 


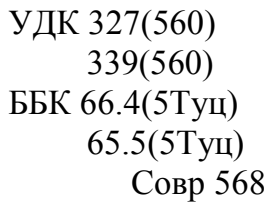

Серия «Библиотека Национального исследовательского института мировой экономики и международных отношений имени Е.М. Примакова»

Рецензент: кандидат философских наук В.А. Надеин-Раевский

Под редакцией к.и.н. И.Я. Кобринской, д.э.н. Л.С. Вартазаровой, к.полит.н. С.В. Уткина

Авторский коллектив:

А.А. Давыдов, П.А. Гудев, И.Д. Звягельская, С.В. Жуков,

И.Я. Кобринская, Е.М. Кожокин, А.Б. Крылов, В.А. Кузнецов, Д.Б. Малышева, Н.М. Мамедова, В.В. Наумкин, И.А. Свистунова,

Э.Г. Соловьев, Н.Ю. Сурков, К.М. Труевцев, Ф.О. Трунов, Н.Ю. Ульченко, Б.Е. Фрумкин, П.В. Шлыков

Совр 568

Современная Турция: тренды развития и значение для России. Под ред. Л.С. Вартазаровой, И.Я. Кобринской, С.В. Уткина. М.: ИМЭМО РАН, 2019. - 54 с. ISBN 978-5-9535-0550-5

DOI:10.20542/978-5-9535-0550-5

Брошюра посвящена тенденциям развития современной Турции. Рассмотрены внутри- и внешнеполитические, а также экономические факторы. Отдельное внимание уделено зонам риска для российско-турецких отношений. На основе материалов ситуационного анализа ИМЭМО РАН.

Modern Turkey: Development Trends and the Meaning for Russia / Vartazarova L, Kobrinskaya I., Utkin S., eds. - Moscow, IMEMO, 2019. - 54 p.

ISBN 978-5-9535-0550-5

\section{DOI:10.20542/978-5-9535-0550-5}

The brochure describes trends in development of modern Turkey. It includes analysis on the country's home and foreign policies, as well as economic development. A special attention is paid to risk zones for Russian-Turkish relations. Based on a situation analysis held at IMEMO.

\section{Публикации ИМЭМО РАН размещаются на сайте https://www.imemo.ru}


1. ВНУТРИПОЛИТИЧЕСКАЯ СИТУАЦИЯ В ТУРЦИИ ......................... 6

1.1. ОСНОВНЫЕ ТЕНДЕНЦИИ В ОБЩЕСТВЕННО-ПОЛИТИЧЕСКОЙ ЖИЗНИ ...........6

1.2. ФАКТОРЫ УСТОЙЧИВОСТИ РЕЖИМА Р.ЭРДОГАНА................................9

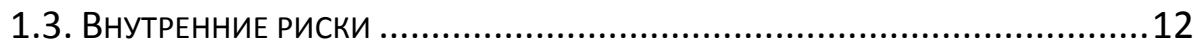

2. КРИЗИСНЫЕ ЯВЛЕНИЯ В ЭКОНОМИКЕ ..................................13

3. ВНЕШНЯЯ ПОЛИТИКА Р. ЭРДОГАНА И ПОЗИЦИИ ОСНОВНЫХ АКТОРОВ В РЕГИОНЕ ..........................................................16

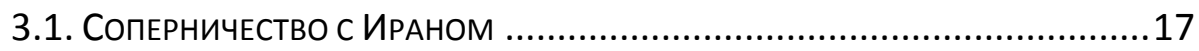

3.2. ПОИСК НОВОГО БАЛАНСА В ОТНОШЕНИЯХ С ИЗРАИЛЕМ .......................20

3.3. ОТНОШЕНИЯ С ИРАКОМ И СИРИЕЙ В КОНТЕКСТЕ КУРДСКОГО ВОПРОСА ....22

3.4. ОСОБЕННОСТИ ОТНОШЕНИЙ СО СТРАНАМИ ЗАЛИВА...........................23

3.5. НАПРЯЖЕННОСТЬ В ОТНОШЕНИЯХ С США И НАТО ..............................26

3.6. НОВЫЕ АКЦЕНТЫ В ОТНОШЕНИЯХ С ЕВРОПЕЙСКИМ СОЮЗОМ .................33

4. ЗОНЫ НАПРЯЖЕННОСТИ В ОТНОШЕНИЯХ РОССИИ И ТУРЦИИ ...37

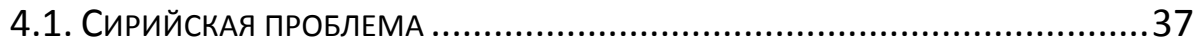

4.2. «СОРЕВНОВАНИЕ» ЗА ВЛИЯНИЕ НА ПОСТСОВЕТСКОМ ПРОСТРАНСТВЕ ........38

4.3. РИСКИ СОТРУДНИЧЕСТВА В ВЫСОКОТЕХНОЛОГИЧНЫХ СФЕРАХ .................45

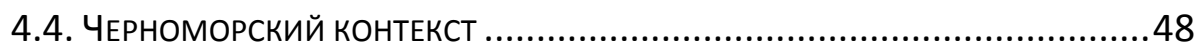

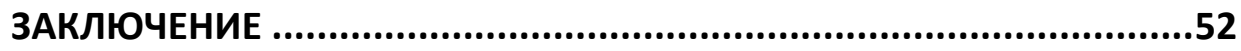




\section{Введение}

К концу второго десятилетия XXI века Турция подходит с новыми амбициями и серьезными трудностями. Нынешний президент, Реджеп Тайип Эрдоган, планомерно укрепляя свою власть на протяжении пятнадцати лет, фактически попытался реформировать страну в соответствии со своими убеждениями, конечно, в той степени, в которой это позволяют существующие экономические, ресурсные и внешние ограничители.

Хотя исход политических битв вряд ли когда-то бывает окончательным, на ближайшие годы, по-видимому, именно Р.Эрдоган будет формировать свою эпоху турецкой истории. Придя к власти с консервативной повесткой, он неизбежно осознает, что для закрепления в числе глобальных лидеров Турции необходим экономический и технологический прогресс. Сможет ли президентская стратегия обеспечить такой результат, не поставив под угрозу прочность заточенной на лидера политической системы - покажет время.

Президент Эрдоган увлечен мегапроектами. В его планах новые туннели, мосты и каналы - инфраструктура, которая должна привлечь инвесторов, обеспечить рабочие места и, в конечном счете, позитивную экономическую динамику. Но экономике свойственны свои железные законы, которые политическим визионерам бывает так тягостно соблюдать. Макроэкономическое нездоровье не удастся преодолеть через масштабные стройки. Докажет ли турецкий президент способность переключиться с решительных мер по консолидации власти на осторожность, умеренность и выверенность рецептов, ведущих к финансовой стабильности?

В последние годы Турция, как с грустной иронией отмечали многие наблюдатели, прошла путь от лозунга «нет проблем с соседями» к реальности, которую было бы правильнее описать как «нет соседей без проблем». Станет ли тенденцией движение в обратном направлении? Возможно ли конструктивное международное взаимодействие в условиях обостряющейся 
конкуренции эгоистичных держав, в том числе на Ближнем Востоке?

Россия - географический сосед, политический и экономический партнер Турции. То, как именно будут разрешены дилеммы турецкого развития, имеет для нас отнюдь не абстрактное значение. На Черном и Средиземном морях, на Ближнем Востоке и в других региональных сочетаниях соседи, успешно работающие друг с другом, максимизируют взаимные выгоды. Соседи, тонущие во внутренних противоречиях и спорах, привлекают «третьих радующихся», а сами теряют, иногда фатально много. Знание и понимание внутренних процессов и внешних устремлений соседей - важная составляющая внешнеполитических успехов.

Настоящая брошюра подготовлена на основе материалов ситуационного анализа, проведенного осенью 2018 г. в Институте мировой экономики и международных отношений им. Е.М.Примакова РАН. 


\section{1. Внутриполитическая ситуация в Турции}

\section{1. Основные тенденции в общественно-политической жизни}

На протяжении последних десяти лет в Турции происходят последовательная консолидация власти в руках президента и изменения в общественной жизни, которые можно охарактеризовать как делиберализацию и десекуляризацию.

Конституционная реформа 2017 г. и досрочные президентские выборы сформировали супер-президентскую систему.

Ее основные черты:

- Упразднѐн пост премьер-министра (пост главы правительства в том или ином виде существовал не только на протяжении всей республиканской истории, но и в период Османской империи). Вместо премьера - назначаемые президентом заместители (вице-президенты), подотчетные не парламенту, а лично президенту - главе государства и исполнительной власти.

- Президент наделен законодательной инициативой и может издавать законы в обход парламента.

- Президент назначает большинство членов Конституционного суда (12 из 15), а также значительное число Совета судей и прокуроров - надзорного органа судебной системы Турции.

- Президент может распускать парламент по любым основаниям, в то же время Парламент не имеет существенных рычагов воздействия на исполнительную власть (в частности, отменено право парламента требовать отчета министров и правительства) за исключением процедуры импичмента, которая обставлена значительными сложностями и трудно реализуема.

- Политическая ответственность президента ограничена только выборами, проходящими раз в пять лет. По новой Конституции формально у президента 2 срока по 5 лет, однако, если в течение второго срока будут объявлены досрочные президентские выборы, два срока «обнуляются». Таким образом, созданы все условия для «пожизненного президентства». 
Государственный контроль средств массовой информации начал расширяться ещѐ в середине 2000-х годов. К настоящему времени крупнейшие CMИ - телеканалы CNN Türk, Kanal D, газета Hürriyet, информационное агентство Doğan Haber Ajans1 и др. стали частью 95\% контролируемых окружением президента медиаресурсов.

Первые значительные шаги по реструктуризации судебной власти правительство ПСР предприняло в 2010 г. в рамках конституционной реформы: поправки в основной закон, представленные как очередной шаг на пути расширения демократии и укрепления правового характера турецкого государства, существенно изменяли состав и принципы формирования Конституционного суда и Высшего совета судей и прокуроров, увеличивая их численный состав и вводя новую процедуру избрания.

В 2013 г. после коррупционного скандала была произведена дальнейшая ревизия судебной системы страны. В начале 2014 г. по итогам выборов в Высший совет судей и прокуроров его состав был заменѐн на кандидатов, поддержанных министерством юстиции. Тогда прозвучала фраза первого вице-председателя Высшего совета судей Мехмета Йылмаза о том, что «судебная власть должна работать в гармонии с исполнительной» 1 .

Одним из первых шагов обновлѐнного Высшего совета судей стало создание системы т.н. «мировых уголовных судов», специализирующихся на выдаче ордеров на арест во время следствия и обжаловании решений об аресте. Тем самым ликвидировалась возможность обжалования ареста в вышестоящей судебной инстанции.

После избрания на пост президента в 2014 г. Эрдоган стал говорить о том, что парламентская система Турции уже стала достоянием прошлого 2 . Крупные функционеры ПСР с чувством удовлетворения признавали, что «все ветви власти в стране исполнительная, законодательная и судебная - в руках ПСР» ${ }^{3}$.

\footnotetext{
${ }^{1}$ HSYK: Seçilirsek yürütmeyle uyumlu çalışacağız / Iyibilgi.com, 1.09.2014. URL: http://www.iyibilgi.com/haber.php?haber_id=338093

${ }^{2}$ Cumhurbaşkanı Recep Tayyip Erdoğan önemli açıklamalar yaptı / Haber Turk, 29.03.2015. URL: http://www.haberturk.com/gundem/haber/1059491-cumhurbaskanirecep-tayyip-erdogan-onemli-aciklamalar-yapti

${ }^{3}$ AKP'li Ensarioğlu: Yasama bizde, yürütme bizde, yargı bizde, her şey bizde! / T24, 5.04.2016. URL: http://t24.com.tr/haber/akpli-ensarioglu-yasama-bizde-yurutme-bizdeyargi-bizde-her-sey-bizde,334979
} 
Накануне путча - в июне 2016 г. - Высший совет судей и прокуроров запустил новую кадровую реформу, в рамках которой через процедуру увольнения и переназначения должны были пройти более 3750 судей и прокуроров ${ }^{4}$. Кадровая реформа обеспечила лояльность элементов системы верховной власти.

13 июня 2016 г. правительство внесло на обсуждение парламента закон, предусматривающей санацию двух высших судебных органов - Высшего апелляционного суда и Государственного совета (высшего административного суда) ${ }^{5}$. Более 700 судей - практически весь кадровый состав этих судов, за исключением их председателей и ряда высших должностных лиц подлежали увольнению и переназначению. Причем большинство действующих судей лишались возможности вернуться к судебной практике, поскольку закон предполагал сокращение их числа в два с лишним раза 6 .

Закон также предусматривал кадровую чистку Центральной избирательной комиссии и Государственного совета: 11 действующих членов ЦИК подлежали ротации, а в Госсовет президент Эрдоган должен был назначить 24-х новых членов. Назначение судей - конституционная прерогатива президента, но случаев, когда президент менял бы четверть Государственного совета, в турецкой истории ранее не было. Конституционная реформа 2017 г. завершила начатый таким образом процесс.

Наиболее ярко тенденция десекуляризации общественной $\boldsymbol{ж}$ системе образования. В 2012 г. Р.Эрдоган объявил о том, что главная задача системы образования - это воспитание «благочестивого поколения" (Dindar Nesil), что можно рассматривать, в определенном смысле, как противопоставление гюленовскому проекту «золотого поколения» высокообразованных мусульман, конкурентоспособных на мировом рынке труда. С этого времени тезис о «благочестивом поколении»

\footnotetext{
${ }^{4}$ Turkish gov't shakes up judiciary with decree shifting more than 3,700 judges, prosecutors / Hürriyet, 7.06.2016. URL: http://www.hurriyetdailynews.com/turkishgovt-shakes-up-judiciary-with-decree-shifting-more-than-3700-judgesprosecutors.aspx? pageID $=238 \& n I D=100164 \&$ NewsCatID $=338$

5"Yüksek yargıya neşter" tasarısı Meclis'e sunuldu / T24, 13.06.2016. URL: http://t24.com.tr/haber/yargitay-ve-danistayin-yapisini-degistiren-yargi-paketimecliste, 345010

${ }^{6}$ Bozdağ " İstinafla Yargitay Ve Daniştay'in İş Yükü Azalacak" / T.C.Adalet Bakanligi, 16.06.2016. URL: http://basin.adalet.gov.tr/Etkinlik/bozdag-istinafla-yargitay-vedanistayin-is-yuku-azalacak
} 
стал неотъемлемой частью риторики ПСР. Именно в 2012 г. правительство ПСР без широкого общественного обсуждения провело реформу системы образования - права выпускников религиозных школ имам-хатибов были расширены, а в программы светских учебных заведений были введены уроки арабского, курсы корановедения и изучения Сунны (жизнеописания пророка Мухаммеда). В результате произошла, во-первых, коммерциализация образования и, во-вторых, вытеснение государственных светских школ школами с серьезной религиозной составляющей учебных программ.

Р.Эрдоган нацелен на обновление политического истэблишмента за счет молодежи, которая воспитана на принципах «благочестивого поколения». Возрастной ценз для участия в выборах в Парламент был снижен - с 25 до 18 лет.

Значимой составляющей процесса десекуляризации выступает джемаатизация общественно-политической жизни в республике. В условиях подавления гюленистов растет количество джемаат-структур, которые набирают силу и активно используются в качестве политических инструментов контроля. Также с 2000-х гг. растет роль исламских финансовых институтов.

\section{2. Факторы устойчивости режима Р.Эрдогана}

Устойчивость политического режнима Р.Эрдогана будет в определяющей мере зависеть от уровня внутриэлитного конфликта. Тенденции к его обострению проявлялись в Турции на протяжении последних 10 лет, но условия для появления оппозиционного лидера оперативно нивелировались.

Оппозиционные политики больше озабочены сохранением своего кресла лидера партии, а не тем, чтобы предложить какую-либо реальную альтернативу той программе, которую выдвинула правящая партия, и, тем более, выступить консолидирующей оппозицию фигурой.

Налицо разобщенность оппозиционных сил, дефицит идей и недостаточная эффективность стратегий. Главный лозунг оппозиции - необходимость положить конец правлению Эрдогана и вернуть Турции парламентскую демократию. В числе обещаний возвращение сирийских беженцев назад в Сирию; повышение 
минимального размера оплаты труда; отмена санитарного сбора; отказ от повышенного денежного довольствия и регулярных дополнительных выплат госслужащим.

Сказывается неудача предвыборного оппозиционного альянса из кемалистов, националистов, либералов и консерваторов (исламистов), а также провал проекта харизматичного кандидата Мухаремма Индже - его интенсивная предвыборная кампания принесла немало дивидендов (миллионные митинги), однако всего этого оказалось мало для победы на президентских выборах.

Кемаль Кылычдароглу, лидер главной оппозиционной силы Народной республиканской партии (НРП, идеологическая основа социал-демократия, кемализм), за годы своего лидерства с 2010 г. не смог вывести партию на качественно новый уровень (в 2018 г. $22,64 \%$ голосов и 146 мандатов) и теряет сторонников. В партии идет борьба за лидерство - Кылычдароглу не желает уступать кресло лидера Мухаррему Индже, показавшему результат лучше (30,64\%), чем НРП.

Эрдогану удалось серьёзно нейтрализовать оппозицию справа, включив Партию националистического движения в правящую коалицию (ПНД - партия, которую некогда называли неофашистской). Этот альянс получил в парламенте 344 мандата (более $57 \%$ мест).

Совокупный потенциал оппозиции по результатам выборов 2018 г. - 256 депутатов (43\% мест). Таким образом, правящая коалиция не имеет всѐ же конституционного большинства в меджлисе - для реализации, в частности, права президента на объявление досрочных парламентских выборов требуется поддержка этого решения 360 голосами депутатов из 600 .

Главная угроза появления политического конкурента на протяжении последних десяти лет исходила из курдской политической среды, поскольку в районах с доминированием курдского населения политическая конкуренция и соперничество между партиями находятся на самом высоком уровне. Курдскими политиками были испытаны разные методы отстаивания своих позиций - и военный, и дипломатический (игра на площадке европейских и международных институтов и организаций), и, наконец, - путь легальной политики, который доказал свою эффективность (третье место по числу мандатов в парламенте на выборах 2018 г.). Р.Эрдогану удалось на сегодня эффективно подавить фактор курдского военного и политического сопротивления. 
Модель военного переворота на сегодняшний день в Турции едва ли реализуема. Чистки в турецкой армии привели к тому, что армия находится в кадровом кризисе. Структурная реформа вооруженных сил, объявленная 31 июля 2016 г. в рамках чрезвычайного положения, внесла значительные изменения, как в систему организации армии, так и в модель военно-гражданских отношений:

- Высший военный совет - регулярный орган, отвечающий за ключевые назначения в армии и традиционно контролируемый военной элитой (глава правительства и министр обороны всегда были единственными гражданскими лицами в Совете), расширен за счет включения в его состав вице-президентов, министров юстиции, внутренних и иностранных дел.

- Начальник Генштаба подчинѐн президенту, а командующие военно-воздушными, сухопутными и морскими силами выведены из под его прямого подчинения и должны отчитываться перед министром обороны, при этом президент получил возможность отдавать приказы командующим армиями напрямую.

- Проведена реформа системы военного образования: все высшие военные училища, несмотря на давние традиции, закрыты; военные академии - кузница высшего офицерства - будут расформированы. Создан Национальный военный университет при Министерстве обороны, на который возложена задача подготовки высших офицеров.

- В сфере военно-гражданских отношений произошло переподчинение важнейших структур: все предприятия, заводы, судоверфи и другие аналогичные объекты, находившиеся под контролем армии, переданы в ведение Министерства обороны; все военные госпитали переподчинены Министерству здравоохранения; командование жандармерией - военной полицией и береговой пограничной охраной передано в ведение Министерства внутренних дел.

- Лица, имеющие отношение к вооруженным силам, лишены права баллотироваться в парламент.

Таким образом, сегодня в Турции армия и военная элита лишены политической субъектности, а институты, которые обеспечивали их политическое и экономическое влияние демонтированы. 


\section{3. Внутренние риски}

Турецкое общество сегодня расколото, причем ни одна из сторон не проявляет стремления к поиску компромисса. Президентская Партия справедливости и развития получила поддержку менее 50\% избирателей, при этом вторая половина - это часть крупных предпринимателей, традиционно ориентированных на ценности республики и торгующих с Западом; студенчество, интеллигенция, значительная часть городских жителей. Однако, оппозиция в Турции, если и будет формироваться, то не в неолиберальном, а в националистическом, исламистском русле, с использованием структур джемаата, поскольку они гораздо меньше контролируются юридической системой, гораздо менее институционализированы и менее прозрачны.

В условиях расколотого общества при реализации негативного экономического сценария (углубление кризисных явлений, затяжная стагнация) существенным становится риск роста напряжённости и гражданского противостояния. Особенно с учетом того, что президент Эрдоган в последние годы дал зелѐный свет на вооружение гражданского населения Турции - по официальным данным за период с 2016 года 2,3 млн. граждан получили разрешение на ношение оружия, при том что в стране остается большое количество незарегистрированного оружия.

- Опасны и разнонаправленные этнические и этноконфессиональные тенденции. Значимую роль начинает играть арабский фактор (к 2-м млн. человек исконно живущих в Турции арабов добавились 3,5 млн. сирийских беженцев, как минимум полмиллиона иракских, а также значительное количество беженцев со всего арабского мира). В то же время нужно учитывать своеобразие самоидентификации современного турка - она не исключает этнически не-турецкое происхождение. 


\section{2. Кризисные явления в экономике}

Турецкая экономика находится в достаточно сложном положении. В августе-сентябре 2018 г. Турция пережила очередную волну девальвации турецкой лиры, в результате чего ее стоимость по сравнению с началом

2018 г. упала на 40\%. Минимального значения курс лиры достиг 10 августа, когда он превысил 7 лир за доллар. На фоне девальвации значительно ускорилась инфляция еѐ уровень с начала года составил более $18 \%$, что является самым высоким показателем с 2004 г. Центральный банк Турецкой Республики 13 сентября 2018 г. в качестве ответной меры повысил ключевую ставку на 625 базисных пунктов до 24\%, тогда как на начало года она составляла $8 \%$. Таким образом, экономика страны переживает период сильной турбулентности. Темпы роста по итогам 2018 г., как ожидается, снизятся и составят 3,8\% против $7,4 \%$ в 2017 г. Но это всѐ же не кризис в его классическом понимании, который трактуется как отрицательные темпы роста по итогам периода.

Модель роста, которую избрала Партия справедливости и развития, обеспечила ей, с одной стороны, успех, но с другой стороны, в ней была заложена «мина замедленного действия» существенная привязка экономики к внешним источникам финансирования. При оценке экономического развития Турции за последние годы было принято говорить в основном о достижениях: финансовой стабилизации, снижении дефицита бюджета, снижении инфляции. Действительно, в государственном секторе разрыв между доходами и расходами существенно сократился, в частности, за счѐт сокращения инвестиционных расходов государства (правда в последнее время они вновь пошли вверх в целях осуществления амбициозных мега-проектов) и снижения бюджетных расходов по обслуживанию государственного долга. Сокращение по этим двум статьям позволило обеспечить некоторое повышение социальных расходов, которое сыграло важную роль в укреплении позитивного имиджа партии перед избирателями. Но в частном секторе инвестиционная деятельность в гораздо большей степени, чем раньше, опирается на внешние займы, что привело к возросшему разрыву между сбережениями и инвестициями. 
Таким образом, суть модели, которой придерживается сегодня Турция, это сокращение бюджетного дефицита при росте дефицита по счёту текущих операций платежного баланса. Начинала ПСР в 2002 г. с весьма скромных значений этого показателя - всего 600 млн. долл. К 2008 году это было уже 42 млрд., пик в 2011 году составил 75 млрд. или 10\% ВВП. Далее в 2015-2016 гг. произошло некоторое затухание. По состоянию на конец третьего квартала 2018 г. дефицит по счету текущих операций составил $6 \%$ ВВП.

Поскольку Турция исповедует модель экономического роста, в рамках которой весьма сильна зависимость от 1) значительных объемов, 2) регулярности и 3) лѐгкости поступления внешнего финансирования - экономика страны чувствительна к любому нарушению одного из названных условий.

Второй причиной структурного характера, определившей кризисные явления в экономике, хотя и несколько менее значимой, чем первая, стала неопределенность статуса Центрального банка, который формально независим от исполнительной власти. В последние годы эта независимость стала существенно нарушаться решениями Р.Эрдогана, сначала в качестве премьер-министра, а затем уже в качестве президента страны. Это по факту означает ограничение свободы Центрального банка в использовании регулирующих инструментов. Конфликт между Эрдоганом и руководством ЦБ начался в 2014 году, когда ЦБ после неудачных попыток удержать курс турецкой лиры посредством валютных интервенций произвѐл двукратное повышение процентной ставки. Президент страны до сих пор остается при убеждении, что рост ставок есть причина роста инфляции. И Центральному банку в условиях прессинга президента трудно своевременно нейтрализовать волны валютной турбулентности.

Поводом для обострения экономической ситуации в Турции стала вся та совокупность обстоятельств, которую Р. Эрдоган, а вслед за ним и другие турецкие официальные лица, склонны считать причинами, а именно - «манипулятивные внешние атаки», или «систематические атаки крупных экономических игроков, в частности США». Речь идѐт о решении США (на фоне политического скандала с Турцией по поводу задержания пастора Эндрю Брансона) резко увеличить таможенные пошлины на 
турецкую сталь и угрозы расширить экономические санкции в отношении страны.

Турция, в силу достаточно существенного роста заработных плат, является одной из тех стран, которые, утратив преимущества в сфере дешевого труда, не обзавелась преимуществами, связанными с виртуозным владением и широким использованием высоких технологий.

Руководство страны понимает эту проблему. Была принята новая программа среднесрочного экономического развития на 20192021 гг. с амбициозным названием «Новая Турция», так как к 2023 году - 100-летнему юбилею Турецкой Республики предполагается принципиальное обновление страны. Поставлена задача уменьшения дефицита по счѐту текущих операций с нынешних $6 \%$ до 2,6\% к 2021 году путем снижения зависимости от импорта. Для Турции это означает громадный рывок в технологическом обновлении и диверсификации промышленности, прорыв не только в индустриальном развитии, но и вступление в постиндустриальный период. Достичь этих целей за оставшееся время будет не так просто. Реалии таковы, что на сегодня только 3\% промышленных товаров, производимых в Турции, относятся к группе высокотехнологичных, и эти же 3\% высокотехнологичных товаров зафиксированы в экспорте страны.

Макроэкономические проблемь турции, скорее всего, приведут к долгосрочному сниюению экономической динамики. 


\section{3. Внешняя политика Р. Эрдогана и позиции основных акторов в регионе}

К основным трендам позиционирования Турции на мировой арене следует отнести:

- $\quad$ Повышение активности Анкары на мировой арене

- Форсированное развитие отночений со странами различных регионов

- Борьбу за региональное лидерство на Ближнем Востоке

Руководство Партии справедливости и развития провозгласило претенциозную цель - превращения Турции в одну из ведущих мировых держав. В целом идею укрепления международных позиций страны разделяют и оппозиционные партии. Однако они предпочитают другие пути достижения этой цели. Народно-республиканская партия не поддерживает исламский вектор внешний политики ПСР, недовольна конфликтами с западными союзниками и слишком резкими шагами Эрдогана на Ближнем Востоке. Турецкие националисты традиционно делают акцент на развитии связей с тюркскими народами и занимают жесткую позицию в отношении территориальных и пограничных споров с соседними государствами. В этой связи альянс с националистами, в который ПСР вступила в 2018 г., уже привел к ужесточению подхода Эрдогана к проблеме Кипра и отношениям с Грецией.

В десятилетней перспективе, поскольку способность оппозиционных партий прийти к власти после завершения президентских полномочий Эрдогана на данный момент не очевидна, при сохранении власти у ПСР или возглавляемой ею коалиции, значительные изменения общего внешнеполитического курса маловероятны. 


\section{1. Соперничество с Ираном}

Отношения Ирана с Турцией исторически были сложными и противоречивыми. В настоящее время очевиден тренд их сближения, но обусловлен он не столько внутренними, сколько внешними факторами. Среди этих факторов есть как долговременные, так и кратковременные, и они изменяют баланс сил в борьбе за лидерство в регионе.

Одним из основных факторов, оказывающих сильное воздействие на позицию Ирана в отношении Турции, является сирийский кризис. Участие Ирана в этом кризисе носит и политический, и военный характер. С началом Астанинского процесса позиции Ирана и Турции сблизились, постоянными стали связи на самом высшем уровне. Президент Ирана Хасан Роухани в феврале 2018г. в телефонном разговоре с Эрдоганом говорил о «близких позициях двух стран по региональным и международным вопросам» и даже о стратегическом партнѐрстве. ${ }^{7}$ Тем не менее, разногласия по вопросам власти в Сирии остаются. Турцию настораживает активное участие КСИР в делах региона. Но и Иран достаточно настороженно относится к военным действиям Турции в Сирии. Наиболее отчѐтливо это звучит в статьях известного иранского аналитика Садека Малеки, отражающего настроения части внешнеполитической элиты. Он считает наиболее целесообразным в настоящее время соблюдать осторожность в отношении Турции, «избегать рискованных шагов, которые могут только усугубить геополитическую обстановку на Ближнем Востоке".

Но для обеих стран главным остаётся совпадение взглядов по курдскому вопросу, т.к. сепаратистские тенденции в курдском движении одинаково опасны и для Турции, и для Ирана. Иран учитывает озабоченность Турции из-за поддержки Ираном шиитских движений и организаций в регионе. Упор делается на

\footnotetext{
${ }^{7}$ Dr Rouhani in a phone call with his Turkish counterpart: Iran-Turkey ties should be promoted to strategic level in all fields/Faster implementation of using national currency in business transactions. URL: http://president.ir/en/102822

${ }^{8}$ Иран и Турция: региональные проблемы и консультации в Тегеране. / Pars Today. 8.02.2018. URL: http://parstoday.com/ru/news/middle_east-i83219
} 
общеисламском единстве, появились работы о суфийском наследии, что может рассматриваться как сближающие обе страны шаги.

Иран в своих отношениях с Турцией не может не учитывать и национальный фактор - наличие в стране более $30 \%$ тюркоязычного населения, а также значительной доли курдов, которые активно проявили себя в оппозиционных выступлениях 2018 года. Но Турция старается не акцентировать внимание на проблеме пантюркизма. Показательны слова турецкого аналитика по Ирану Сабира Аскероглу, который считает, что в настоящее время Турция рассматривает дестабилизацию Ирана из-за национального сепаратизма нежелательной для иранских азербайджанцев ${ }^{9}$.

На отношение иранского руководства к Турции влияет позиция Турции в отношении антииранских санкций США. Несогласие Турции с санкционным нажимом США на Иран усилилось с наложением санкций в отношении самой Турции. В августе 2018 г. министр иностранных дел Турции М. Чавушоглу вновь заявил, что «мы не будем применять санкции США против Ирана». ${ }^{10}$ В Нью-Йорке на ассамблее ООН в сентябре 2018 г. Р.Эрдоган сказал Х.Роухани, что «мы будем стоять рядом с вами в противодействии санкциям». ${ }^{11}$

Такая позиция, помимо геополитического измерения, обусловлена экономическими интересами. Экономики стран являются взаимодополняющими. Хотя товарооборот между странами не превышает 10-11 млрд. долл. (в период санкций был ниже), для Ирана Турция является весьма значимым покупателем энергоресурсов - нефти и газа. В 2017г. доля Турции в общем экспорте Ирана составила 11,1\% (4-е место), главным образом за счѐт поставок в Турцию углеводородов. До мая 2018г. Турция за счет иранской нефти обеспечивала более $50 \%$ своих потребностей. Но после заявлений Трампа закупки начали снижаться. Нельзя исключать, что Турция и далее будет снижать закупки иранской нефти, но вряд ли прекратит их. Нет оснований предполагать

\footnotetext{
${ }^{9}$ Турецкий эксперт: «Иран и Турция — вечные конкуренты на Кавказе и на Ближнем Востоке» / Новая эпоха. 27.09.2018. URL: https://yenicag.ru/tureckiyyekspert-iran-i-turciya-vechny/

${ }^{10}$ Turkey Not Interested in US' Iran Sanctions / Financial Tribune. 10.08.2018 URL: https://financialtribune.com/articles/national/91530/turkey-not-interested-in-us-iransanctions

${ }^{11}$ On the sidelines of the UN General Assembly in New York; Iranian, Turkish Presidents discuss most important bilateral, regional and international issues / President of Iran. URL: www/president.ir/en/106227
} 
увеличение мощности действующего газопровода из Тебриза, но можно допустить поставки иранского газа в Турцию из иракской газопроводной сети через строящиеся Ираном газопроводы в Басру и Багдад.

В иранском импорте доля Турции меньше - в 2017г. составила 4,4\%, но это - 3-е место после ОАЭ, являющихся фактически ре-экспортером, и Китая. В турецком экспорте преобладают промышленные товары, в т.ч. высокотехнологичные, в чем Иран заинтересован. В 2016г. турецкие инвестиции в Иран достигли 1,2 млрд.долл. В Турции работают 3 тыс. иранских компаний, главным образом в азербайджанских провинциях и свободной экономической зоне «Арас». В 2018г. открылся турецкий торговый дом.

Соглашение о преференциальной торговле было подписано еще в 2014 г., т.е. в период действия антииранских санкций. Ведутся переговоры о включении в этот договор ряда товаров, главным образом, продукции нефтехимии, автомобильных запасных частей, изделий из алюминия и стали, одежды, т.е. тех позиций, которые попали под санкции США. ${ }^{12} 6$ октября 2018 г. Иран и Турция подписали 3 соглашения по садоводству, пчеловодству и ветеринарии.

С учетом новых санкций Турцией и Ираном 19 октября 20172. было подписано Соглашение об использовании в торговле национальных валют. В качестве агентских банков назначены иранский «Мелли» и турецкий «Зираат». Банки выделили 1,4 млрд. долл. и их эквиваленты в качестве аккредитивов. Иранский банк «Мелли» открыл первый аккредитив уже 16 апреля для финансирования иранской торговли с Турцией. ${ }^{13}$ В предыдущий период санкций был отработан финансовый механизм хавала, главным образом через cappapbl - пункты обмена валюты, действующие по границе с Турцией, но достигнутое соглашение имеет принципиальное значение, как пример использования современного инструмента, в том числе и для других стран. Это особенно важно в условиях американских санкций на продажу

\footnotetext{
${ }^{12}$ PTA With Turkey Not in Iran's Interests / Financial Tribune. 21.04.2018 https://financialtribune.com/articles/economy-domestic-economy/85000/pta-withturkey-not-in-iran-s-interests

${ }^{13}$ Iran, Turkey Start Using Nat'l Currencies in Trade / Financial Tribune. 17.04.2018. https://financialtribune.com/articles/economy-business-and-markets/84832/iran-turkeystart-using-nat-1-currencies-in-trade
} 
Ирану валюты и золота, что ставилось в вину Турции Соединенными Штатами до заключения СВПД.

Таким образом, обе страны объединяет совпадение по ряду геополитических интересов, а такэе экономическая заинтересованность в расширении связей, особенно в условиях санкционного давления не только на Иран, но и на Турцию. Но санкции против турецких компаний, например, поставляющих авиационные запчасти нетурецкого производства иранским авиакомпаниям, ужесточаются. Пока Европа и Китай выступают за поддержку реализации СВПД, позиция Турции - такая же, однако с учетом сложного состояния экономики стране возможно придется корректировать степень поддержки Ирана. В самом Иране политическая и экономическая ситуация также напряжена. Из-за осложнившегося экономического положения возможен уход из власти сторонников реформаторского толка, т.е. сторонников сохранения СВПД, нельзя исключать прихода к власти военных и, следовательно, изменений во внешней политике. Это ставит Турцию в ситуацию сложного и не очень прогнозируемого выбора.

Тактическое объединение Ирана и Турции для противодействия региональной политике Запада вполне вероятно. $\mathrm{He}$ исключено, что чрезмерный «произраильский крен» в ближневосточной политике новой американской администрации может стать для Турции стимулом к дальнейшему укреплению связей с Ираном. Вместе с тем Анкара и Тегеран по-разному видят будущее Ближнего Востока и свою миссию в регионе, и в этом кроется глубокое противоречие между ними ${ }^{4}$, которое будет препятствовать формированию прочного турецко-иранского альянса.

\section{2. Поиск нового баланса в отношениях с Израилем}

В отношениях Турции с Израилем сохраняется тревожная неопределѐнность. Некоторое время тому назад Турция была для Израиля идеальной моделью исламского государства, с которым можно поддерживать прекрасные отношения. Это время, в связи с

\footnotetext{
${ }^{14}$ Ahmad Majidyar. Rouhani, Erdogan pledge cooperation, but mutual distrust remains / Middle East Institute. 8.02.2018. // URL: http://www.mei.edu/content/io/rouhanierdogan-pledge-cooperation-mutual-distrust-remains.
} 
политическими преобразованиями в Турции, практически закончилось, но осталась ориентация Израиля на то, чтобы окончательно маргинализировать палестинскую проблему, сосредоточившись на борьбе с Ираном, а следовательно - на союз с максимально большим числом суннитских государств (очень активная работа ведется с Саудовской Аравией, Египтом, Эмиратами).

Роль Турции уходит на второй план, особенно в свете той сильной анти-израильской риторики, которую Турция долэнна неизбежно предъялять исламскому миру на фоне признания Соединенными Штатами Иерусалима как единой столицы Израиля и других конфликтных вопросов. Учитывая значение сирийских беженцев для Турции и их отношение к палестинской проблеме, понятно, что всѐ это осложняет ее отношения с Израилем и, более того, заставляет сегодня Израиль ориентироваться на других игроков. Тем более что для Израиля ключевое значение имел и имеет сегодня союз с Иракским Курдистаном. Израиль был единственным государством, признавшим законность референдума в этом регионе. Для Израиля сегодня, судя по всему, важно продвигаться к созданию широкой курдской автономии, и Турция не может этого не учитывать.

Израиль не возражает против присутствия Турции на севере Сирии. В их представлении это способствует сдерживанию Ирана.

У Израиля есть в отношениях с Турцией озабоченности и ограничители, связанные с его отношениями с другими суннитскими государствами, в частности, с Египтом. Очень велика роль Турции в катарском кризисе и в фактической нейтрализации экономической блокады Катара государствами Персидского залива. Здесь, возможно, совпадают интересы Израиля и Турции в том, чтобы в одном случае тайно, в другом явно, поддерживать Катар и обеспечивать его благосклонное отношение к Израилю.

Израилю не нравится сближение между Турцией и Палестинской автономией. Турция в последние годы ориентировалась на поддержку ХАМАС и Газы, но сегодня некоторое содействие оказывается и ФАТХ.

Уменьшение роли Турции во внешнеполитической стратегии Израиля, возможно, произошло и потому, что Израиль развивает стратегию «новой периферии», больше нацеленной именно на арабский мир. Но, все же, весьма вероятен возврат на определенном этапе к союзу с Турцией, которая остается ключевым игроком в суннитском мире. 


\section{3. Отношения с Ираком и Сирией в контексте курдского вопроса}

Перспективы перекройки границ Ирака и Сирии, на часть территории которых исторически претендовала Турция, подталкивают Анкару к активному участию в событиях в этих странах, тем более что и в Сирийском, и в Иракском Курдистане на турецкой границе стоят вооружѐнные отряды одной из главных оппозиционных сил Турции - Рабочей партии Курдистана (РПК).

В Ираке Турция опирается на часть иракских суннитов и туркоманов (иракских туркменов), традиционно оказывает покровительство опальным иракским политикам-суннитам. Ресурсом влияния Анкары в Ираке служит присутствие там турецкого воинского контингента, ведущего борьбу с РПК. Ослабляет позиции Турции необходимость балансировать между отношениями с центральным правительством и Иракским Курдистаном.

Позиция Турции в отношении Иракского Курдистана это стремление наладить двустороннее сотрудничество, вовсе небезуспешное, потому что Турция является доминирующей силой во внешнеэкономических отношениях этого региона. Иракский Курдистан всерьез и надолго становится субъектом политики в регионе.

В Сирийском Курдистане реализована и работает своеобразная система самоуправления, близкая по духу к идеям лидера РПК Оджалана о так называемой конфедеративной демократии. Практически все управленческие кадры Сирийского Курдистана готовились в Иракском Курдистане.

Позиция Турции по отношению к Сирийскому Курдистану - это попытка его ликвидации, что, скорее всего, не имеет перспектив. В идеале Турция хотела бы видеть в Дамаске лояльный себе режим, а саму Сирию - в качестве зоны своего исключительного влияния. Однако реальные условия позволяют Анкаре пытаться решить лишь задачу-минимум, которая включает недопущение создания независимого или автономного Курдистана, поддержание «полосы безопасности» вдоль турецко-сирийской 
границы и установление своего условного «протектората» над частью территории Сирии.

Попытки Турции играть на противоречиях по курдскому вопросу в Ираке и Сирии мало успешны. На данном этапе Иран является единственной региональной силой, которая изнутри можсет воздействовать на курдский фактор.

\section{4. Особенности отношений со странами Залива}

После начала гражданской войны в Сирии Турция и Королевство Саудовская Аравия (КСА) поддерживают там разные вооруженные оппозиционные группировки «умеренно» исламистского либо салафитского толка (Ахрар аш-Шам и Нусра, соответственно), которые периодически вступали в столкновения друг с другом.

В 2011-2013 гг. главным раздражителем в двусторонних отношениях была поддержка турками «Братьев-мусульман» в Египте. Анкара решительно осудила отстранение от власти Мухаммеда Мурси летом 2013 года. КСА, напротив, приветствовало действия египетских военных и оказало масштабную финансовую помощь правительству Абдель-Фаттаха ас-Сиси.

Эр-Рияд возмущен тем, что Анкара вторгается в его традиционную сферу влияния - Аравийский полуостров и соседние регионы. Так, Турция в 2017 году поддержала Катар (помогла смягчить последствия его блокады), создала военные базы в Катаре и Сомали, ведѐтся строительство военно-морской базы в Судане (на побережье Красного моря).

Одним из поводов для недовольства КСА является также сотрудничество Турции с Ираном. Фактический правитель, наследный принц Мухаммед бин Салман, публично рассуждает о «треугольнике зла», куда входят Иран, Турция и исламские экстремисты. В марте 2018 года, во время визита в АРЕ, принц заявил на встрече с редакторами ведущих СМИ, что президент Эрдоган хочет восстановить халифат, а Иран использует «Братьев- 
мусульман» для экспорта революции и терроризма ${ }^{15}$. Впоследствии саудовская сторона выступила с опровержением.

Региональные наблюдатели отмечают, что КСА разыгрывает курдскую карту против Ирана и Турции. Эр-Рияд де-факто поддержсивает стремление курдов (суннитов) к независимости, поскольку появление курдского государства в Ираке или в Сирии позволит расколоть так называемый «ииитский полумесяц».

Прочной экономической базы для развития двусторонних отношений между Анкарой и Эр-Риядом нет. Торговоэкономические связи отражают негативную динамику в политической сфере. Общий объѐм торговли после 2012 года постепенно снижался (с 8 до 5 млрд. долл. в 2016 году ${ }^{16}$ ), однако, происходило это главным образом за счет сокращения почти вдвое турецкого импорта из КСА. Как представляется, на фоне ухудшения отношений Анкара решила снизить зависимость (если, вообще, можно говорить о таковой) от саудовской нефти. Примечательно, что саудовцы не снижают объемы импорта. Объемы инвестиционного сотрудничества также скромные - саудовские инвестиции в Турции не превышают 2 млрд. долл. ${ }^{17}$ В этом плане КСА значительно уступает соперникам в лице Катара. В КСА работают около 200 турецких компаний с оборотом около 1 млрд. долл., в то время как в Катаре объем контрактов почти в 15 раз больше.

В 2015-2017 гг. КСА активно пыталось наладить сотрудничество с Турцией, но этому мешает большое количество политических противоречий. В настоящее время страны следует рассматривать как соперников. Впрочем, со стороны Эр-Рияда прослеживается стремление избежать дальнейшего ухудшения отношений.

Сближению Турции и Катара способствовала ставка руководства обеих стран на умеренных исламистов на Ближнем Востоке. После начала «арабской весны» Доха и Анкара поддержали «Братьев-мусульман» в АРЕ, исламистов в Ливии,

\footnotetext{
${ }^{15}$ Saudi Arabia calls Iran, Turkey and Islamic Militants The 'New Axis Of Evil,' Egypt Reports / Newsweek. 7.03.2018. URL: https://www.newsweek.com/saudi-arabia-callsiran-turkey-muslim-militants-new-axis-evil-egypt-reports-835697

${ }^{16}$ Turkey-Saudi Arabia Economic and Trade Relations (2016) / MFA of Turkey. URL: http://www.mfa.gov.tr/turkey_s-commercial-and-economic-relations-with-saudiarabia.en.mfa
}

17 KSA-Turkey trade set to soar / Arab News. 13.04.2016. URL: http://www.arabnews.com/economy/news/909611 
вооруженные группировки в Сирии. Обе страны демонстрируют наличие региональных амбиций, тем самым они бросают вызов традиционному лидеру суннитского мира - КСА. В настоящее время отношения Катара и Турции носят характер стратегического партнерства.

Турция является гарантом безопасности для Катара. В июне 2017 года турецкий парламент одобрил размещение в Катаре военной базы. Она рассчитана на 5000 военнослужащих и несколько сотен единиц боевой техники. Планируется также размещение боевой авиации и флота. Катар закупает крупные партии турецкого вооружения. По сути, он превращается в крупнейшего внешнего инвестора в турецкий ВПК, развитию которого Анкара придаѐт большое значение.

От Турции зависит продовольственная безопасность эмирата. Это проявилось после того, как в 2017 году соседние страны установили блокаду Катара. Именно масштабные поставки из Турции позволили избежать кризиса и скачка цен ${ }^{18}$.

В сентябре 2018 года было подписано соглашение об экономическом и торговом партнѐрстве (либерализация торговли, поставки энергоносителей по льготным ценам ${ }^{19}$. Катар является вторым по значению иностранным инвестором (свыще 20 млрд. долл.). Турецкие компании получили 11,6 млрд. долл. контрактов в рамках подготовки к ЧМ 2022, всего же турецкие фирмы реализуют контракты на 14,8 млрд. В августе 2018 года эмир Тамим пообещал инвестировать еще 15 млрд. долл. ${ }^{20}$, чтобы поддержать Турцию, которая переживает экономический кризис. Объем торговли сравнительно небольшой (что отчасти объясняется малыми размерами эмирата), в 2017 году товарооборот достиг 1,3 млрд. Есть планы довести объѐм торговли до 5 млрд. долл. ${ }^{21}$ в год (в первую

\footnotetext{
${ }^{18}$ Turkey sends Qatar food and soldiers, discusses Gulf tensions with Saudi / Reuters. 22.06.2017. URL: https://uk.reuters.com/article/uk-gulf-qatar-turkey-saudi/turkeysends-qatar-food-and-soldiers-discusses-gulf-tensions-with-saudi-idUKKBN19D0CY

19 Turkey, Qatar sign major trade agreement / Yeni Safak. 4.09.2018 URL: https://www.yenisafak.com/en/economy/turkey-signs-major-trade-agreement-withqatar-3440278

${ }^{20}$ Qatar Repays Diplomatic and Military Debt to Turkey with Offer Of \$15B In Financial Support / Forbes.16.08.2018. URL: https://www.forbes.com/sites/dominicdudley/2018/08/16/qatar-repays-debt-turkey-15bsupport/\#345615fa9f59

${ }^{21}$ Turkey seeks to 'increase trade with Qatar to $\$ 5$ billion' / The NewArab. 27.02.2018 URL: https://www.alaraby.co.uk/english/news/2018/2/27/turkey-to-increase-trade-withqatar-to-5-billion
} 
очередь, за счет энергоносителей). Поставлена цель комплексного развития отношений, чтобы у военно-политических связей была прочная экономическая база.

Стремление Анкары распространить свое влияние в арабском мире - активная позиция в сирийском кризисе, формирование влиятельного по своим военным и финансовым возможностям суннитского блока с Катаром - привело к противостоянию между Турцией и квартетом (КСА, ОАЭ, Египет, Бахрейн), которое, впрочем, не имеет перспектив перерастания в прямой военный конфликт.

\section{5. Напряженность в отношениях с США и НАТО}

Попытки Турции осуществлять автономные шаги и ставить национальные интересы выше блоковой солидарности уже привели к конфликтам Анкары с традиционными союзниками (США, ЕС, HATO).

Отношения с США в период президентства Д.Трампа стабильно сохраняют обостренный характер и тенденции к ухудшению. Несмотря на длительный характер союзных связей в рамках Североатлантического альянса (НАТО), в Соединенных Штатах за последние годы существенно усилились опасения за сохранность их в таком статусе. Высокий уровень напряжённости между США и Турцией приобрел стратегически-системный характер, чему способствуют процессы на уровне двусторонних отношений, а также во многом противоречащие друг другу интересы обеих стран на Ближнем Востоке.

В группе политических процессов и факторов нужно отметить следующие.

- Негативное воздействие на уровне двусторонних отношений продолжает оказывать пребывание Ф. Гюлена на территории Соединенных Штатов. После попытки военного переворота середины 2016 года трансформация турецкой политической системы, включающая высокую централизацию власти в руках президента, сопровождается широким подавлением оппозиционных Р. Эрдогану сил, среди которых главным антагонистом является Ф. Гюлен и его структуры. Длительное нежелание Вашингтона его экстрадировать подвигло власти Турции 
арестовывать граждан США на территории Республики, включая ряд лиц с двойным гражданством (Турции и США).

- Внутриполитические тенденции в Турции стали служить поводом для усиления давления со стороны Вашингтона. На уровне экспертно-политического сообщества США все чаще стали упоминаться проблемы с верховенством закона и соблюдением прав человека, подавлением оппозиции, особенно в отношении курдов, подчеркиваются проблемы с коррупцией. Это уже послужило поводом для введения точечных санкций в августе 2018 г. против министров юстиции и внутренних дел турецкого правительства в рамках «Глобального закона Магницкого» ${ }^{22}$. Сохраняется потенциал для введения санкционных и иного рода ограничений по широкому спектру политических вопросов, среди которых особую значимость могут иметь: признание геноцида армян в Османской империи на уровне федеральной власти США ${ }^{23}$; введение запрета на въезд турецким официальным в США ${ }^{24}$; введение обязательства США голосовать против предоставления кредитов через Мировой банк и Европейский банк реконструкции и развития (за исключением случаев оказания гуманитарной помощи) $)^{25}$.

$\begin{array}{ccccc}\text { - } & \text { Стратегические интересы США и Турции зачастую } \\ \text { входят } & \text { п } 1 \text { противоречия } & \text { из-за } & \text { стремления Анкары }\end{array}$ диверсифицировать свое сотрудничество с большей ориентацией на

\footnotetext{
${ }^{22}$ Treasury Sanctions Turkish Officials with Leading Roles in Unjust Detention of U.S. Pastor Andrew Brunson. U.S. Department of the Treasury, 01.06.2018. URL: https://home.treasury.gov/news/press-releases/sm453

23 Turkey 2017 Human Rights Report. U.S. Department of State, 2017. URL: https://www.state.gov/documents/organization/277471.pdf; Power and Corruption in Erdogan's Turkey: Context and Consequences. The Bipartisan Policy Center, 27.11.2017. URL: https://bipartisanpolicy.org/wp-content/uploads/2017/11/BPCNational-Security-Power-and-Corruption-in-Erodgans-Turkey.pdf; Flanagan S. A Turning Point in U.S-Turkish Relations? RAND Corporation, 21.05.2017. URL: https://www.rand.org/blog/2017/05/a-turning-point-in-us-turkish-relations.html; A resolution expressing the sense of the Senate regarding the 102nd anniversary of the Armenian Genocide. U.S. Congress, 24.04.2017. URL: https://www.congress.gov/bill/115th-congress/senateresolution $/ 136 /$ text?q= $\% 7 \mathrm{~B} \% 22$ search $\% 22 \% 3 \mathrm{~A} \% 5 \mathrm{~B} \% 22$ armenia + genocide $\% 22 \% 5 \mathrm{D} \%$ $7 \mathrm{D} \& \mathrm{r}=1$

${ }^{24}$ S. 3108 Department of State, Foreign Operations, and Related Programs Appropriations Act for Fiscal Year 2019, Sec. 7046(d). URL: https://www.congress.gov/bill/115th-congress/senate-bill/3108/text ${ }^{25}$ S. 3248 Turkey International Financial Institutions Act. URL: https://www.congress.gov/bill/115th-congress/senate-bill/3248/text
} 
регион (в частности, в рамках пантюркизма с элементами исламизма). Позиции стран зачастую не находят совпадения по широкому кругу вопросов в отношениях с Россией, Ираном, Катаром, курдами, со странами Европейского союза, в рамках арабо-израильского конфликта.

Наибольшую обеспокоенность в США вызывают вопросы военно-политического характера. Главным среди них на текущий момент является закупка Анкарой у Москвы зенитно-ракетных систем С-400 «Триумф ${ }^{26}$. Вашингтон начал вырабатывать контрмеры. Во-первых, может быть задействован механизм закона «О санкционном противодействии противникам США» ${ }^{27}$, дающий возможность введения санкций (крупные штрафы или длительный срок заключения ${ }^{28}$ ) против лиц, вовлеченных в транзакции с оборонным сектором РФ. Во-вторых, Конгресс рассматривает вероятность ограничения поставок Анкаре истребителейбомбардировщиков F-35, однако Турция вовлечена в его производство, что усложняет реализацию таких мер.

\section{Другой значимой точкой напряжсения является военное сотрудничество США с курдскими вооружсенными} формированиями на севере Сирии, которых турция считает mеррористами. Соединенные Штаты воздерживаются от открытых политических обещаний курдам относительно политического статуса их региона, но, в то же время, не оказывают достаточного давления для сдерживания их в прежних границах, в частности, восточнее р. Евфрат ${ }^{29}$.

\footnotetext{
${ }^{26}$ Khan B. Turkish Government Invites Bids for F-35 System Integration Contract. Quwa Defense News and Analysis Group, 10.01.2018. URL: https://quwa.org/2018/01/10/turkish-government-invites-bids-for-f-35-systemintegration-contract/; Insinna V. US official: If Turkey buys Russian systems, they can't plug into NATO tech. Defense News, 16.11.2017. URL: https://www.defensenews.com/digital-show-dailies/dubai-air-show/2017/11/16/usofficial-if-turkey-buys-russian-systems-they-cant-plug-into-nato-tech/; McLeary P. Top NATO General (A Czech) To Europe: 'Grow Up'. Breaking Defense, 07.03.2018. URL: https://breakingdefense.com/2018/03/top-nato-general-a-czech-to-europe-growup/

${ }_{27}$ P.L. 115-44 Countering America's Adversaries Through Sanctions Act, Sec. 231, August 2, 2017. URL: https://www.congress.gov/bill/115th-congress/housebill/3364/text

28 P.L. 95-223 International Emergency Economic Powers Act, Sec. 206(b), (c), October 28, 1977.

${ }^{29}$ Erdogan, Trump emphasize importance of Manbij roadmap: Turkish presidency. Reuters, July 16, 2018. URL: https://www.reuters.com/article/us-turkey-usmanbij/erdogan-trump-emphasize-importance-of-manbij-roadmap-turkish-presidency-
} 
В 2018 г. турецкое юридическое лицо впервые с 2015 г. попало вместе с группой других зарубежных кампаний (в том числе из РФ, Саудовской Аравии, Сирии, Египта и прочих стран) под санкции в рамках закона по нераспространению оружия массового уничтожения Ираном, КНДР и Сирией ${ }^{30}$.

Существенное беспокойство в Соединенных Штатах вызывает ряд торгово-экономических вопросов. Среди них первостепенное значение имеет политика Турции в контексте антииранского санкционного режсима. У Соединенных Штатов есть достаточно оснований для того, чтобы распространить его действие на турецкую экономику. Так, за период действия санкций, замороженных в рамках Совместного всеобъемлющего плана действий (СВПД) с января 2016 года, ряд иранских банков обходили эти санкции с помощью турецкого государственного банка «HalkBank» ${ }^{31}$. Из-за этого банку может быть присвоен статус «Иностранного уклониста от санкций», что будет иметь существенный эффект на турецкую экономику, поскольку «HalkBank» занимает около $10 \%$ от финансового сектора страны. ${ }^{32}$. Выход Соединенных Штатов из СВПД может повлечь значительные последствия для турецкого бизнеса, активно укрепляющего связи с Ираном ${ }^{33}$.

Сохраняется значительная почва для интенсификации негативных последствий санкционного и иного давления в отношении Турции, имеющей глубокие экономические связи с

idUSKBN1K61EV ; As Turkey Attacks Kurds in Syria, U.S. Is on the Sideline. The New York Times, January 22, 2018. URL: https://www.nytimes.com/2018/01/22/world/middleeast/turkey-syria-kurds-us.html

30 Complete list of sanctioned entities under Nonproliferation Sanctions. U.S. Department of State, 30.04.2018. URL: https://www.state.gov/documents/organization/284359.pdf

${ }^{31}$ The Biggest Sanctions-Evasion Scheme in Recent History. The Atlantic, 04.01.2018. URL: https://www.theatlantic.com/international/archive/2018/01/iran-turkey-goldsanctions-nuclear-zarrab-atilla/549665/

32 E.O. 13608 Prohibiting Certain Transactions With and Suspending Entry Into the United States of Foreign Sanctions Evaders With Respect to Iran and Syria. Federal Register, Vol. 77, No. 86, May 3, 2012. URL: https://www.treasury.gov/resourcecenter/sanctions/Programs/Documents/fse_eo.pdf; Turkey: Cracking Down on Sanctions Violations, Washington Wounds Ankara. Stratfor, 04.01.2018. URL: https://worldview.stratfor.com/article/turkey-cracking-down-sanctions-violationswashington-wounds-ankara

33 Turkish-Iranian trade revived amid growing cooperation in Syria. Al-Monitor, 02.03.2018. URL: https://www.al-monitor.com/pulse/originals/2018/03/turkey-iransyria-trade-revived-amid-rapport.html 
США и их союзниками (60,9\% турецкого экспорта и 59,19\% импорта приходились на страны Европы и Северной Америки в 2016 году $\left.^{34}\right)$. Так, введенные 10 августа 2018 г. США пошлины на алюминий $(20 \%)$ и сталь $(50 \%)$ послужили катализатором экономического кризиса в Турции ${ }^{35}$.

Высокий уровень напряженности между США и Турцией связан также с расхождением подходов двух стран к НАТО. После окончания «холодной войны» Турция тяготела к классической трактовке НАТО как института, обеспечивающего безопасность Запада, а США оперировали расширением зоны ответственности альянса как инструмента своего глобального доминирования. Проекцией этого фундаментального расхождения стали и полярные взгляды стран на проблемы международной безопасности, оценку «хороших и плохих» террористов, «хороших и плохих» региональных игроков.

Турция всегда отличалась от большинства стран-членов НАТО способностью совершать относительно независимые от альянса шаги на региональном уровне. На современном этапе потенциал разногласий между Анкарой и альянсом увеличился в связи с ростом угроз безопасности на Ближнем Востоке. Вместе с тем у Турции по-прежнему много общих с альянсом интересов и стратегий. Для Анкары сохраняет актуальность и «ядерный зонтик» НАТО, особенно в свете амбиций Ирана.

В целом Турция, обладающая вторыми по численности вооружѐнными силами среди стран-участниц НАТО (386 тыс.чел. в 2018 г.) ${ }^{36}$, поддерживает процесс наращивания (особенно в количественном плане) возможностей Североатлантического альянса, начавшийся с 2014-2015 гг. Анкара, во-первых, постепенно увеличивает свои расходы на военные цели (на $0,08-0,10 \%$ от объѐма ВВП ежегодно), а, во-вторых, принимает полноправное участие в наращивании возможностей основных военных механизмов Альянса:

\footnotetext{
${ }^{34}$ Atlas of Economic Complexity. Center for International Development at Harvard University. URL:

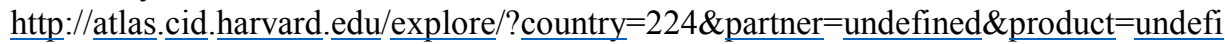

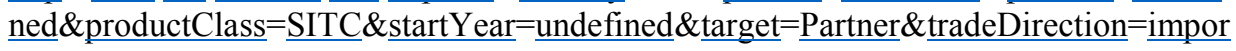
$\frac{\text { t\&year }}{35}=2016$

${ }_{35}$ США решили повысить вдвое пошлины на алюминий и сталь из Турции. Ведомости, 10.08.2018. URL:

https://www.vedomosti.ru/economics/news/2018/08/10/777890-ssha

${ }^{36}$ Defence Expenditure of NATO Countries (2011-2018). COMMUNIQUE PR/CP (2018) 091. - Brussels, 10 July 2018. - P. 12.
} 
- в 2021 г. Турция будет комплектовать бригаду сверхвысокой боевой готовности (Very High Readiness Joint Task Force) из 5 тысяч военнослужащих в составе сил быстрого реагирования (общая численность - 40 тысяч с 2015 г.);

- Р. Эрдоган поддержал на Брюссельском саммите НАТО (10-11 июля 2018 г.) реализацию инициативы НАТО по созданию дополнительных тактических сил под командованием Альянса - 30 батальонов (эквиваленты 8 бригадам), 30 тактических авиаэскадрилий и 30 кораблей с готовностью 30 суток. Их должны на постоянной основе выделить к 2020 г. страны-участницы Альянса: Турция одной из первых заявила о готовности осуществить эти меры. Один из штабов для управления этими войсками будет создан на базе управления 3-го армейского корпуса турецкой армии;

- Турция (а также Испания и Португалия) выступила инициатором развѐртывания на своей территории нового дополнительного командования НАТО (учитывая рост присутствия Альянса вдоль его южных границ в Европе).

Эти решения, озвученные в ходе Брюссельского саммита НАТО в июле 2018 г., сопровождались демонстрацией сотрудничества президента Турции и генерального секретаря Альянса $^{37}$. Помимо этого, Турция сохраняет военное присутствие в Афганистане под эгидой НАТО в рамках операции «Resolute Support».

Турция активно предоставляет НАТО свои надводные военные корабли (и базы для захода) в акваториях Средиземного, Мраморного и Чѐрного морей. Официальная Анкара не выразила никаких протестов против усиления присутствия НАТО в Румынии и Болгарии. Однако Турция (в отличие от стран Балтии, Польши и даже Норвегии) не запросила дополнительного военного присутствия НАТО на своих границах в условиях стратегического ухудшения отношений евроатлантического сообщества и РФ.

Страны-участницы

обеспокоенность развитием
HATO сотрудничества Турции с Китаем и Россией ${ }^{38}$. Кроме того, негативную реакцию Запада вызывает факт достаточного

\footnotetext{
${ }^{37}$ Turkey Prepares for More Roles in NATO //Atlantic Council. URL: http://www.atlanticcouncil.org/blogs/natosource/turkey-prepares-for-more-roles-in-nato

${ }^{38}$ Турция ожидает российские ЗРК С-400 в ближайшее время - Эрдоган // Звезда.

URL: https://tvzvezda.ru/news/vstrane i mire/content/201808311242-ux 50.htm
} 
динамичного сотрудничества Турции с Россией и Ираном по урегулированию «сирийской проблемы».

Одновременно растѐт круг стратегических вопросов, по которым усиливается разброс позиций официальной Анкары и Белого дома и в то же время растѐт число точек соприкосновения с континентальными европейскими державами НАТО. Это сохранение «ядерной сделки» (и углубление торговоэкономического сотрудничества) с Ираном и подготовка мер широкого, как экономического, так и политико-дипломатического, идеологического характера в ответ на недружественные действия США в отношении партнѐров (в частности, введение повышенных таможенных пошлин и в целом ослабление экспортного потенциала стран, обладающих реальным производством). Это не способствует углублению практического военного сотрудничества США и Турции.

«Камень преткновения» в отношениях Анкары и еѐ европейских партнѐров по НАТО - торможение сотрудничества между Альянсом и Европейским союзом, государством-членом которого является Республика Кипр.

В свою очередь, и государства-партнѐры Турции по Североатлантическому альянсу стремятся не допустить возможности использования официальной Анкарой статьи 5 Вашингтонского договора для втягивания в масштабные военнополитические кризисы. Эта тенденция отчѐтливо проявилась после уничтожения в воздушном пространстве Турции российского бомбардировщика Су-24 24 ноября 2015 г. США и Франция немедленно призвали к деэскалации напряжѐнности ${ }^{39}$. Примечателен и скачкообразный характер мер ФРГ по военному сотрудничеству с Турцией с 2015 г. В первую очередь, он обусловлен стремлением Германии избежать втягивания в качестве участника боевых действий в вооружѐнный конфликт на территории Сирии.

Вероятность выхода Турции из НАТО невелика; еѐ рост может быть обусловлен углублением кризиса в отношениях США, а также контрмерами партнѐров по НАТО в отношении действий Турции на Ближнем Востоке - особенно в Сирии и Ираке. Примечательно, что большинство военных шагов в этом регионе и

\footnotetext{
${ }^{39}$ Nato meets as Russia confirms one of two pilots dead after jet shot down - as it happened //The Guardian. 24.11.2015. URL:

https://www.theguardian.com/world/live/2015/nov/24/russian-jet-downed-by-turkishplanes-near-syrian-border-live-updates.
} 
Турция, и еѐ государства-партнѐры по НАТО, предпринимают без согласования друг с другом и часто вступают в конкуренцию. Так, в феврале - марте 2018 г. в г. Африн (САР) возникла парадоксальная ситуация: турецкие войска несли потери от использования силами самообороны курдов вооружений, предоставленных США и европейскими партнѐрами по НАТО.

\section{6. Новые акценты в отношениях с Европейским Союзом}

Исторически Европейский Союз рассматривал Турцию как продолжателя кемалистских традиций секуляризации общественнополитического устройства, отхода от идеологии исламизма, переориентации с имперской «оттоманской» внешней политики на строительство национального государства европейского типа «с нулевыми проблемами» c соседями. Турцию трактовали как важного партнѐра в обеспечении геополитических интересов Европы, особенно в военно-политических аспектах отношений со странами Варшавского договора (благодаря связям в рамках НАТО) и странами ближневосточного региона (продвижение Турции как модели исламской демократии и современной рыночной экономики). Страны ЕС поддержали вхождение Турции в Совет Европы (1949 г.) и ОЭСР (1961 г.), а в 1963 г. подписали Соглашение об ассоциации, открывавшее Турции возможность создание Таможенного союза с ЕЭС, а в перспективе - членства в этой организации. Тогда же были созданы правовые рамки для массовой трудовой миграции турок в ЕС (прежде всего в ФРГ). В результате в 2017 г. число жителей с турецкими корнями в странах ЕС достигло почти 5 млн. чел (около 1\%). Почти 3 млн. из них живут в ФРГ (составляя около 3,5\% населения, причем $17 \%$ родились уже в Германии), остальные - преимущественно в Голландии и Франции.

Эти тенденции усилились в 1990-е гг. после расnада СЭВ, Вариавского договора и СССР и окончания «холодной войны». В новых условиях ЕС фактически принял стратегию на максимальное сближение с Турцией, прежде всего в экономической сфере. В 1995 г. он заключил Соглашение о таможенном союзе с Турцией, а уже в 1999 2. предоставил ей 
статус страны-кандидата в члены ЕС. В начале 2000-х Турция активно проводила требуемые для вступления реформы (отменила смертную казнь, сняла часть ограничений на базовые свободы, расширила культурные права меньшинств и т.п.). Однако уже в конце первого премьерства Р.Эрдогана реформы затормозились и на фоне дискриминации Турцией судов и самолѐтов из Республики Кипр Совет ЕС в 2006 г. решил не открывать 8 переговорных глав и не закрывать другие, пока Турция не выполнит все свои обязательства. Затем вето на продолжение переговоров наложила Франция, а в 2009 г. - Кипр. Финансовый кризис 2008 - 2010 гг. ещѐ более осложнил ситуацию и фактически заморозил переговоры. Сдвиги в отношениях начались только после 2012 г. Были заключены Соглашение ЕС-Турция о реадмиссии с запуском «диалога о визовой либерализации» (2013 г.), договорѐнности о модернизации Таможенного союза и открытии новой главы в переговорах о вступлении в ЕС (2015 г.). В марте 2016 г. было принято Заявление ЕС-Турция, «перекрывшее» Восточносредиземноморский маршрут нелегальной миграции в ЕС через греческие острова в Эгейском море и сухопутную границу с Болгарией. В обмен Турция получала финансирование содержания на своей территории сирийских беженцев в размере 3 млрд. евро.

Однако, уже в конце 2016 г. отношения Турции с ЕС вновь оказались в кризисе. Непосредственным поводом для этого стали массовые нарушения прав человека в рамках чрезвычайного положения, введѐнного в Турции после попытки военного переворота в июле 2016 г. Но причины для этого кризиса отношений - глубже и серьезнее. "эрдогановской Турции» как в стратегическом цивилизационном и геополитическом партнере, тем более - союзнике.

Совет ЕС в конце 2016 г. вновь прекратил открытие новых глав переговоров о членстве Турции и отказался от конкретных шагов в переговорах о модернизации Таможенного союза. Буксуют и переговоры о введении безвизового режима для въезда граждан Турции в страны Шенгенской зоны (хотя его получили Грузия, Молдова и Украина, не являющиеся кандидатами в члены ЕС).

ЕС фактически заменяет долгосрочную стратегию в отночении Турции кратко- и среднесрочной тактикой, основанной на инструментально-прагматическом подходе: "Держать Турцию не слишком близко, но и не слишком далеко». Не принимая формальных решений по прекращению переговоров о членстве в ЕС, модернизации Таможенного союза, визовой 
либерализации, ЕС фактически ставит их в зависимость от возобновления внутренних реформ, торможения ползучей исламизации и проведения боле разумной внешней политики. Это ясно показал саммит ЕС - Турция в марте 2018 г., с большим трудом «продавленный» председательствовавшей тогда в ЕС Болгарией. Из 5 обсуждавшихся на встрече проблем (сотрудничество по управлению миграционными потоками, общность интересов в борьбе с терроризмом, верховенство права в Турции, действия Турции в Восточном Средиземноморье и Эгейском море, участие Турции в военных действиях в Сирии) договориться удалось фактически лишь по первому вопросу.

В то же время ЕС намерен продолжать контакты с Турцией на разных уровнях и по разной проблематике, чтобы предотвратить дальнейшую изоляцию Турции, снизить непредсказуемость еѐ действий и нестабильность в регионе.

В свою очередь, Турция избегает серьезной конфронтации c ЕС по соображениям экономической и геополитической безопасности. Сотрудничество в рамках Таможенного союза ЕСТурция имеет экзистенциальное значение для турецкой экономики. В 2017 г. ЕС занимал первое место во внешнеторговом обороте (41\%), экспорте (около 47\%) и импорте (более 36\%) Турции. В накопленных в Турции за 2003 -2017 гг. 193 млрд.долл. прямых иностранных инвестиций (ПИИ) на ЕС приходится более $43 \%$. Из примерно 58 тыс. действующих в Турции предприятий с иностранным участием $38 \%$ создали компании ЕС. Причем, несмотря на политические разногласия, это участие растет. В 2017 г. из 6,6 млрд.долл. ПИИ в Турции страны ЕС обеспечили 4,5 млрд. или $68 \%$.

Для ЕС значение экономических связей с Турцией гораздо ниже, хотя также весомо. В 2017 г. она занимала 5-е место во внешнеторговом обороте ЕС (4,1\%), 4- е место (4,5\%) в экспорте и 5 -е - в импорте $(3,8 \%)$. Из 154 млрд.долл. оборота $10 \%$ составляло положительное сальдо в пользу ЕС (с 1996 г. оно приблизилось к 295 млрд.долл.).

Турция занимает 7-е место по степени привлекательности для инвесторов из ЕС. Только за 2005-2015 гг. общий трансфер прибыли компаний ЕС от инвестиций в экономику Турции превысил 26 млрд.долл.

Эти результаты получены при всех нынешних ограничениях для Турции в рамках Таможенного союза - исключение из него продукции сельского хозяйства, угольной и сталелитейной 
отраслей, а также услуг (по которым Турция имеет конкурентные преимущества); недопуск турецких компаний к госзакупке стран $\mathrm{EC}$; «гармонизация» турецкого регулирования внешнеэкономических связей к правилам ЕС без права участия в установлении этих правил; неравноправное положение Турции в реализации соглашений ЕС о свободной торговле с третьими странами (например, Канадой, Японией) и др. Со своей стороны, Турция по числу ограничительных мер на экспорт из ЕС (13) занимает 5-е место после Индии, Китая, США и Бразилии. Устранение этих препятствий после модернизации Таможенного союза могло бы существенно укрепить достаточно хрупкую экономику Турции и способствовать усилению влияния Евросоюза на нее.

Отношения с Евросоюзом остаются сложным вопросом для внешней политики Анкары. Разочарование пробуксовкой процесса евроинтеграции и возмущение двойными стандартами по отношению к Турции входит в коллизию с определяющей ролью ЕС во внешней торговле Анкары ${ }^{40}$. Вопрос о беженцах служит как инструментом давления на ЕС, так и позволяет Анкаре повысить заинтересованность Брюсселя в диалоге. Продолжение переговоров c EC необходимо турецкому руководству для прочности международных позиций страны, наличия противовеса США, сохранения своей уникальности в мусульманском мире и обеспечения многовекторного курса во внешней политике.

${ }^{40}$ Diş Ticaret İstatistikleri // Türkiye İstatistik Kurumu. Resmi İnternet Sitesi. URL: http://www.tuik.gov.tr/PreTablo.do?alt_id=1046. 


\section{4. Зоны напряженности в отношениях России и Турции}

К числу основных, требующих постоянного мониторинга зон напряженности в российско-турецких взаимоотношениях следует отнести:

- Сирию

- Постсоветское пространство (Южный Кавказ, Центральная Азия, Украина)

- Высокотехнологичные сферы сотрудничества

- Черноморские проливы и шельф.

\section{1. Сирийская проблема}

$\begin{array}{rccc}\text { По } & \text { мере приближения урегулирования сирийского } \\ \text { конфликта «на земле» происходит, во-первых, усиление }\end{array}$ противоречий внутри астанинской тройки - между Россией, Турцией и Ираном. Во-вторых, усиливается разрыв между «качественными параметрами» процессов военного и политического урегулирования, поскольку последний в Женеве практически застопорился.

Россия больше всего заинтересована в конвертации успехов в Сирии в политический успех. Но в Женеве его не следует ожидать в ближайшее время, так как мотивация сторон конфликта к его урегулированию резко снизилась, и не видно рычагов еѐ повышения. Из трѐх основных женевских корзин есть продвижение, но не впечатляющее, лишь по второй - конституционной корзине.

У участников «астанинской тройки совершенно разные представления о будущем Сирии и часто диаметрально противоположные интересы. Главный механизм, который был придуман для астанинского формата - это механизм зон 
деэскалации. На какой платформе дальше «дружить» пока непонятно.

На сегодня Идлиб - один из тактических узлов напряженности в отношениях России и Турции. Существует сценарий, при котором Сирийская арабская армия будет стремиться взять под контроль исключительно транспортные артерии, проходящие через провинцию Идлиб (а одна из них - через сам город Идлиб). Но даже в этом случае реакция Турции и возможности новых договоренностей находятся в зоне серьѐзной неопределѐнности - Анкара не собирается отказываться от задачи сохранения своего влияния хотя бы над частью территории Сирии.

В средне- и долгосрочной перспективе напряэенность в российско-турецких отночениях по Сирии связана с проблемой курдов. Россия заинтересована в том, чтобы было достигнуто соглашение между Дамаском и курдами об интеграции курдов в единое сирийское политическое пространство. Но российские усилия в этом направлении наталкиваются на турецкую позицию - с точки зрения Анкары курды YPG (Отряды народной самообороны вооружѐнное формирование Высшего курдского совета, участвующее в сирийском вооруженном конфликте) ни в личном качестве, ни в качестве организации не могут участвовать ни в каких переговорных форматах. Здесь позиции Дамаска и Турции оказываются близки - и те, и другие не заинтересованы в усилении курдов.

\section{2. «Соревнование» за влияние на постсоветском пространстве}

Центральная Азия не является приоритетом торговоэкономической и военной политики Турции. Несмотря на усилия Анкары по развитию экономического сотрудничества со странами этого региона, оно в целом несопоставимо с экономическим влиянием более мощных игроков - Китая, США, ЕС, России. В последние годы, вследствие ослабления инвестиционного потенциала Турции, ее реальное экономическое сотрудничество со странами ЦА имеет тенденцию к сокращению. 
Некоторым центральноазиатским государствам (в основном Казахстану, Киргизии, Туркменистану) Турция с 1990-х годов предоставляет финансовую помощь в виде грантов, кредитов и технической поддержки. Основные проекты в ЦА реализуют такие крупные турецкие инвесторы как холдинги Калик и Йылдырым, а также общественные организации (Турецкое агентство по сотрудничеству и развитию - ТІКА). Товарооборот Турции с Казахстаном и Туркменистаном превышает 2 млрд. долл., и почти 800 турецких фирм сейчас работают в этих странах. Товарооборот с Кыргызстаном составляет более 500 млн.долл. Турецкие компании в основном задействованы в строительстве, в области телекоммуникаций, текстильной промышленности.

\section{Из центральноазиатских государств наиболее}

продвинутые отномения у Турции с Казахстаном. В октябре 2009 года между ними было подписано соглашение о стратегическом партнѐрстве, а в мае 2012 года был создан Совет стратегического сотрудничества высокого уровня (его 3-е заседание прошло в сентябре 2018 г. с участием Назарбаева). ${ }^{41}$ Товарооборот между Казахстаном и Турцией достиг своего пика - 3,5 млрд. долл. в 2012 г. Но с тех пор происходит неуклонное снижение этого показателя, и в настоящее время доля товарооборота с Турцией составляет лишь 2,5\% от общего внешнеторгового оборота Казахстана.

Турция так и не предложила странам региона никакой альтернативы надежной системы безопасности, в то время как Россия такие гарантии предоставляет посредством ОДКБ. Для Центральной Азии это стало одним из важных аргументов против полной интеграции под эгидой Турции. Весьма показательно, что Турция практически не принимала участия во взаимодействии и системе сотрудничества по наиболее важным, ключевым вопросам региональной безопасности - решению межтаджикского конфликта (в 1990-е годы) и длящегося по сегодняшний день афганского кризиса.

Не имея достаточных ресурсов для доминирования в сферах экономики и безопасности, Турция попыталась использовать связи в культурно-образовательной области. Так, в Центральной Азии действует Парламентская

${ }^{41}$ Nazarbayev proposes avenues for cooperation at Turkic speaking states summit // Astana Times, 04.09.2018. URL: https://astanatimes.com/2018/09/nazarbayevproposes-avenues-for-cooperation-at-turkic-speaking-states-summit. 
ассамблея тюркоязычных стран, Совет старейшин, Всемирная ассамблея тюркских народов, которая занимается изучением общих исторических корней тюркской культуры. Международная организация по совместному развитию тюркской культуры и искусства (ТЮРКСОЙ), основанная в 1993 г. в Алматы, по принципам работы приближается к ЮНЕСКО, но не ограничивает свою деятельность культурно-просветительской сферой. В центре ее внимания находятся также вопросы политических и торговоэкономических отношений между тюркоязычными странами Центральной Азии.

К началу 2000-х годов в Казахстане, Киргизии Узбекистане, Туркмении функционировало около двадцати турецких школ и два университета: Казахско-Турецкий и Киргизо-Турецкий, открытых при активном содействии Министерства образования Турецкой Республики и при поддержке общины Ф. Гюлена. Однако Узбекистан решил свернуть студенческие обмены и сотрудничество в области образования с Анкарой, заявив, что обучение в Турции способствует радикализации студентов и крайне негативно влияет на национальную безопасность и стабильность и Узбекистана, и всей Центральной Азии. А после разрыва Эрдогана с Гюленом Турция настояла на закрытии большинства гюленовских школ в ЦА ${ }^{42}$.

Несмотря на то, что по некоторым направлениям Россия и Турция являются конкурентами в ЦА, в этом регионе имеются некоторые предпосылки для их сотрудничества ${ }^{43}$, чему благоприятствует ряд объективных факторов:

- выгодное географическое положение Турции, которая контролирует Черноморские проливы и играет роль своеобразного моста между Европой и Азией, что открывает перед Россией и странами Центральной Азии дополнительные возможности в плане реализации собственных экономических и политических интересов;

- способность Турции и России как крупных евразийских государств со значительным мусульманским населением играть

\footnotetext{
42 Duran B. Erdoğan's warning on FETÖ threat in Kyrgyzstan// Daily Sabah, 06.09.2018. URL: https://www.dailysabah.com/columns/duranburhanettin/2018/09/06/erdogans-warning-on-feto-threat-in-kyrgyzstan.

43 См. подробнее: Малышева Д. Россия и Турция в Центральной Азии: партнерство или соперничество? // РСМД, 23.12.2014 // http://russiancouncil.ru/analytics-and-comments/analytics/rossiya-i-turtsiya-vtsentralnoy-azii-partnerstvo-ili-sopern.
} 
роль посредников в отношениях между странами Центральной Азии, Западом и миром ислама. Основа для российско-турецкого сотрудничества с государствами Центральной Азии - активное неприятие ими радикального исламизма;

- многовекторная политика, взятая на вооружение всеми центральноазиатскими государствами, может быть использована Россией и Турцией для углубленного сотрудничества со странами региона в двустороннем формате.

Взаимодействие России и Турции в ЦА может проходить по следующим направлениям:

- Сотрудничество двух стран в рамках евразийской интеграции, где особую роль могут сыграть экономические министерства и государственные структуры России и Казахстана, заинтересованные в интенсификации торгово-экономических отношений с Турцией в энергетике, торговле, туризме.

- Энергетические проекты с участием России, центральноазиатских государств-экспортѐров (Казахстана, Туркменистана, Узбекистана), а также Турции как крупнейшей в Евразии страны-транзитѐра энергоресурсов.

Сотрудничество военных и дипломатических ведомств России и Турции в сфере поддержания региональной безопасности. Решать эту проблему наиболее оптимальным образом можно в рамках ШОС, в которой Турция с 26 апреля 2013 г. участвует в статусе партнера по диалогу.

- Определѐнные возможности для сотрудничества открываются перед Россией и Турцией в Центральной Азии в сфере противодействия преступности, незаконному обороту наркотиков, нелегальному перемещению людей, товаров, оружия и пр. Подобное взаимодействие может быть осуществлено по линии правоохранительных структур России и соответствующих государственных структур Турции, а также по линии учреждѐнной в 2013 г. в Баку Евразийской ассоциации правоохранительных органов с военным статусом в составе Турции, Азербайджана, Киргизии и Казахстана. Ассоциация ставит своей целью сотрудничество входящих в неѐ государств в деле противодействия организованной преступности, террористической и контрабандной деятельности, активности радикальных групп.

Но российско-турецкое взаимодействие в ЦА имеет определенные ограничители и пределы, главный из которых культурно-цивилизационный пласт (язык, культура), где Россия и Турция являются конкурентами. Россия стремится расширить 
ареал влияния русского языка, русской культуры. Анкара продвигает идею общего турецкого дома, единого для Турции и центральноазиатских государств языка, форсирует переход стран региона с кириллицы на латиницу, делая это достаточно успешно. Турция стремится утвердить себя в Центральной Азии в качестве нового центра культурного и политического притяжения, и даже, возможно, мотора альтернативного российскому общетюркского интеграционного проекта. Но пока о таком интеграционном проекте можно говорить лишь в перспективе, когда Турция преодолеет существенные проблемы в собственном экономическом развитии.

В целом же на постсоветском пространстве почва для разногласий между Россией и Турцией имеется не столько в ЦА, сколько на собственно российских территориях, где компактно проживают тюркоговорящие народы, или же на Южном Кавказе.

Регион Южного Кавказа является приграничным по отношению к Турции, что, конечно, делает его с точки зрения турецкой политики более важным. Главным союзником Турции в этом регионе является Азербайожсан. Первоначально были большие надежды по поводу лозунга «единой турецкой нации» из двух государств, или трех государств, если туда включать Республику Северного Кипра. Но в дальнейшем этот оптимизм угас, и интеграционного проекта на этой почве не возникло. Турция выстроила свои тесные и союзнические отношения с Азербайджаном строго на двусторонней межгосударственной основе. В экономической сфере Турция демонстрирует большой эгоизм. Она добивается максимально выгодных для себя условий сотрудничества с Азербайджаном, в том числе в энергетике, в плане энергетического транзита и установления цен на азербайджанские энергоносители. Это вызывает раздражение в Азербайджане, который болезненно относится к такому эгоизму «старшего брата».

Военно-техническое тесное сотрудничество Турции с Азербайджаном продиктовано характером отношений с Арменией. Между Турцией и Арменией так и не было установлено дипломатических отношений. Армения требует признать геноцид армян, что может предполагать компенсацию со стороны турецкого государства. Для Турции это категорически неприемлемо, как и для Азербайджана.

По отношению к Грузии политика Турции также проводится в тесной координации с Азербайджаном. оба государства заявляют о приверженности стратегическому «тройственному союзу» Грузия - Азербайджан - Турция. Но в этом союзе Грузия 
играет роль «объекта» политики своих соседей. В связи с проживанием турецких граждан в Грузии возникают конфликты по поводу строительства все новых мечетей, причѐм не только в Аджарии, но и во внутренних районах Грузии.

По отношению к частично признанным государствам Турция ведѐт принципиально разную политику. Южнная Осетия рассматривается в общем грузинском контексте. В отношении Абхазии ведётся очень активная политика. Турция опирается на турецких граждан абхазского и северокавказского происхождения - потомков махаджиров. Экономическая активность сосредоточена, прежде всего, в рыболовстве, строительстве, гостиничном бизнесе. В 2014 г. Абхазию посетила официальная делегация парламента Турецкой Республики. Во время президентских выборов 2014 г. права избирателей получили проживающие на территории Турции абхазы. Голосование происходило на избирательных участках в Стамбуле.

В настоящее время, в целом, политика Турции на Южном Кавказе не имеет конфронтационного настроя по отночению к России. Оба государства заинтересованы в недопущении милитаризации Чѐрного моря и прихода сюда внешних сил. В будущем характер политики Турции на Южном Кавказе будет определяться ситуацией в регионе, а также общим контекстом международных отношений. Причин для возникновения острых противоречий пока не фиксируется.

Наибольшие расхождения в позициях Анкары и Москвы по украинской проблематике касаются признания новых реалий в Крыму и воссоединения полуострова с Российской Федерацией. Политическим руководством Турции неоднократно была чётко артикулирована позиция относительно непризнания нового cmamyca Крым. Сам Р.Эрдоган неоднократно осуждал присоединение Крымского полуострова к РФ, «репрессивную политику» в отношении крымских татар в «аннексированном Крыму», выражал поддержку территориальной целостности Украины.

На протяжении нескольких десятилетий с момента распада СССР Анкара оказывала поддержку (материальную, политическую, дипломатическую) крымско-татарскому движению. С этим связаны и определѐнные расчѐты на возвращение Крыма в сферу влияния Турции (многочисленные публикации и публичные выступления бывшего министра иностранных дел и премьер-министра страны 
А.Давутоглу, одного из основателей концепции «неоосманизма», и других политических деятелей-приверженцев этой идеологии).

Крымско-татарская диаспора в Турции имеет большое влияние. Она довольно многочисленна - по оценкам, как минимум, 2 млн. чел. А.Давутоглу и целый ряд других видных и известных турецких политиков считаются потомками выходцев из Крыма. Функционируют имеющие политическое влияние общества культуры и взаимопомощи крымских татар (дернеки). Во многом через крымско-татарские дернеки поддерживались материально, финансировались «Меджлис крымско-татарского народа», Курултай, Всемирный конгресс крымских татар. Этот фактор на обозримую перспективу не позволит существенно трансформировать турецкую позицию по Крыму.

В 1993 г. крымскими татарами была создана своя образовательная структура - Крымский инженерно-педагогический университет в Симферополе. Университет функционирует и сегодня как государственное бюджетное учреждение, на 7 факультетах в нѐм обучается порядка 10 тыс. чел., имеются филиалы в Джанкое, Керчи и Евпатории.

Сейчас крымско-татарская община расколота. Часть крымско-татарской элиты, включая муфтия, занимает пророссийские позиции. Ряд членов Меджлиса вошли в структуры крымского правительства. Муфтий перерегистрировал структуры муфтията в соответствии с российским законодательством. М.Джемилѐв и Р.Чубаров - лидеры части крымско-татарской общины, которая, уехав на Украину, находится в состоянии войны с РФ. Инициативы блокады Крыма исходили, в том числе, от крымских татар. Большая часть крымско-татарской общины - люди, которые не особенно интересуются политикой и успешно занимаются бизнесом в Крыму.

Турция, несомненно, продолюсит оказывать по различным каналам помощь крымским татарам. Но сегодня для руководства страны это направление не является приоритетным.

Другой сложный «украинский вопрос» в российско-турецких отношениях - военно-техническое сотрудничество Киева и Aнкары. В России часто, вслед за публикациями в украинской прессе, масштабы этого сотрудничества существенно преувеличиваются. Но каких-то серьѐзных заделов так и не создано и значимых подвижек, по сути, нет. Для Турции важно заимствование некоторых военных технологий, которыми могла бы 
поделиться Украина. В частности, с 2016 г. идѐт сотрудничество по совместному производству радиолокационной техники ${ }^{44}$. На Украине соответствующие производственные мощности были расположены еще в советское время. Турция также заинтересована в двигателях, в том числе для своего танка «Алтай», который она с переменным успехом проектирует и испытывает на протяжении полутора десятилетий. В 2015 г. по ряду причин сорвался контракт с австрийцами на приобретение двигателей для бронетанковой техники, и Турция переключила свои усилия, в том числе, на взаимодействие с Украиной - но в плане не приобретения, а совместного проектирования. Киев, в свою очередь, интересует приобретение турецких беспилотников «Байрактар» в разведывательном и ударном оснащении. Украинские СМИ активно развивают тему локализации их производства на территории страны, но не ясно, удастся ли об этом договориться с турецкой стороной ${ }^{45}$

\section{3. Риски сотрудничества в высокотехнологичных сферах}

\section{Энергетические проекты}

Турция - второй важнейший рынок для Газпрома на западном направлении. Серьезных рисков со стороны конкурентов здесь не предвидится.

Спрос на газ в Турции в 2017 г. вырос после пятилетней стагнации, во многом, но не исключительно, потому что Газпром пошѐл на ценовые скидки для Турции. Если такая политика Газпрома продолжится, можно ожидать небольшого прироста (5-15 млрд. куб. м газа) в перспективе 10-15 лет. Турция, как и любой

\footnotetext{
44 В апреле 2016 г. Государственный концерн «Укроборонпром» и турецкая компания «HAVELSAN» подписали коммерческое соглашение о совместном производстве радиолокационной техники по стандартам НАТО.

45 Жирохов М. Дорого и сердито. Получит ли Украина ударные турецкие беспилотники // Деловая столица. 2018. 7 ноября. URL: http://www.dsnews.ua/politics/dorogo-i-serdito-poluchit-li-ukraina-udarnye-turetskiebespilotniki-07112018080000; Касьянов Ю. Зачем Украина покупает никому ненужные турецкие беспилотники // Главред. 2018. 10 ноября. URL: https://glavred.info/opinions/10025573-zachem-ukraina-zakupaet-nikomu-ne-nuzhnyetureckie-bespilotniki.html
} 
другой крупный импортер энергетических ресурсов, придерживается политики диверсификации импорта, строит терминалы СПГ. У Анкары хорошие отношения с Катаром, что не означает предоставления Турции преференций для того чтобы вытеснить с турецкого рынка Газпром. Конкурентом может являться Иран, который тоже является экспортером трубопроводного газа в Турцию.

Центральный вопрос - сможет ли Турция трансформироваться в крупный транзитный хаб для экспорта газа из каспийского региона. По мнению экспертов, это скорее миф. Речь об этом идѐт последние 25-30 лет, но никаких прорывов не видно. Во-первых, в силу того, что в Европе идѐт «энергетическая революция» - опережающими темпами строятся именно ветровые и солнечные электростанции. Во-вторых, Турция как крупный газовый хаб не отвечает экономическим интересам крупнейших потребителей газа в Южной Европе, например, Италии. И, втретьих, Турция отстает от стремительной перестройки финансовой и банковской системы стран Европы с опорой на цифровизацию и т.н. «комплаенс» (когда банки, для того чтобы продолжать действовать на рынках Европы, обязаны раскрывать всю информацию о сделках, клиентах, о клиентах клиентов и т.д.), а также из-за усиления политики по противодействию отмыванию денег.

С позиции инвестора, оценивающего инвестиционные риски, цепочка поставки газа «Туркменистан - Азербайджан - Грузия Турция - Греция - Албания» - избыточный риск. Актуализация такой цепочки потребует, как минимум 10-15 млрд. долл., и не видно рыночных причин тому, чтобы потенциальные инвесторы предоставили такой огромный объѐм финансирования. Каспийская декларация - не более чем рамочный документ, протокол о намерениях.

Ни в одном релевантном долгосрочном прогнозе спроса и импорта газа Европой нет каспийского газа, кроме 8-10 млрд. куб. м из Азербайджана (на этот объем еще в 2013 г. были подписаны контракты между Азербайджаном и европейскими компаниями). Тогда этот проект имел политическую поддержку США. Сейчас, с экономической точки зрения, США в нѐм не заинтересованы, поскольку продвигают свой газ на мировом рынке.

\section{Военно-техническое сотрудничество}


В Турции слишком малая часть военного бюджета тратится на закупки вооружения и военной техники. При общих затратах в 2017 г. на оборону порядка 13 млрд. долл. (у европейских держав НАТО этот показатель колеблется в диапазоне 39-65 млрд. долл.) более $54 \%$ военного бюджета Турции приходится тратить на жалованье личному составу; а ещѐ до $22 \%$ - на снабжение (в первую очередь, питание и амуницию). В результате лишь немногим более $20 \%$ реально расходуется на разработку и закупку ВиВТ, что существенно снижает возможности военно-технического сотрудничества.

Ещѐ одна «болевая точка» - отсутствие собственных производств большинства видов военной продукции. Исключение составляет лишь производство БМП и БТР. Танковый парк и фрегаты в основном обновляются за счѐт ФРГ, и глубокие расхождения между двумя странами (в связи с миграционным кризисом) могут создать проблемы для закупок новых партий этих видов военной продукции. Расхождения с администрацией Д.Трампа ограничивают доступ в ближайшей перспективе к получению прорывных технологий. Турция существенно отстаѐт от других держав НАТО (особенно США, Великобритании и Германии) в деле роботизации своих вооружѐнных сил - в первую очередь, создания парка беспилотной разведывательной авиации.

Сегодня перед Анкарой стоит серьѐзная проблема обновления парка вооружений и военной техники, без чего невозможно позиционирование Турции как полновесного регионального игрока. Республика пытается решить эту задачу несколькими путями:

- изменяя структуру военного бюджета в пользу ВиВТ путѐм последовательного сокращения численности вооружѐнных сил - с 427 до 386 тыс. военнослужащих ${ }^{46}$ за период 2013-2018 гг. (заодно решается и проблема увольнения неблагонадежных офицеров);

- налаживая сборку иностранной военной продукции на своей территории, а также диверсифицируя обмены военными технологиями.

Как показывают плановые закупки турецкими вооруженными силами военной техники, главными военными поставщиками будут оставаться партнеры по НАТО. Даже в случае углубления кризиса в отношениях с администрацией Д.Трампа,

\footnotetext{
${ }^{46}$ Рассчитано на основе: Defence Expenditure of NATO Countries (2011-2018). COMMUNIQUE PR/CP(2018)091. - Brussels, 10 July 2018. - P. 10.
} 
возможности для России выхода на масштабный турецкий оборонный рынок, являются достаточно ограниченными - это могут быть только вспомогательные системы. В части тяжелой техники, на закупки которой официальная Анкара планирует тратить наибольшие суммы, основными поставщиками все-таки останутся Германия и Франция, поскольку модернизацию имеющегося парка вооружений и военной техники выгоднее всего осуществить за счет продукции тех стран, где были произведены нынешние образцы вооружений. Сохранение сотрудничества именно с этими странами в военно-технической области является важным аргументом в пользу полноценного участия Турции в деятельности НАТО и еѐ сдержанности в особо важных для партнѐров вопросах в Сирии и Ираке.

Развитие ВТС традиционно имеет для официальной Анкары существенную политическую подоплеку. И закупки российских комплексов ПВО С-400 (решение было обнародовано в сентябре 2017 г.) не только и не столько укрепят в реальности оборону страны, сколько продемонстрируют диверсифицированность военно-технических контактов, причѐм в сфере новейшей техники. Возможно, что Р.Эрдоган надеется в перспективе использовать этот фактор для подталкивания своих партнѐров по НАТО к более глубокому военно-технологическому сотрудничеству.

\section{4. Черноморский контекст}

В числе заявленных Р.Эрдоганом мегапроектов - планы по строительству нового канала, параллельного проливу Босфор, а такюже канала, параллельного Дарданеллам из Эгейского в мраморное море. Возникает вопрос: какие риски и угрозы этот проект несѐт для режима проливов, закреплѐнного в Конвенции Монтрѐ 1936 г.

Первое, что в этой связи необходимо отметить, что Турция является той страной соглашения, как, впрочем, и Российская Федерация, которая безусловно крайне заинтересована в его дальнейшем существовании - режим Конвенции Монтрѐ дает 
Анкаре гораздо больше полномочий по регулированию (контролю) судоходства в проливах, чем Конвенция ООН по морскому праву 1982 года. В случае размывания режима Конвенции Монтрѐ, применение норм и положений Конвенции 1982 г. будет автоматически означать, что данные проливы будут отнесены к категории международных и к ним в полном объеме будет применимо право транзитного прохода, как для гражданских судов, так и для военных кораблей. Правда, существует один немаловажный нюанс - Турция не является полноправным участником Конвенции 1982 г. Однако, США, которые не только не ратифицировали, но и не подписали Конвенцию 1982 г., крайне заинтересованы в либерализации режима прохода через проливы и не откажутся от отстаивания своей точки зрения, согласно которой транзитный проход через международные проливы должен быть гарантирован любым припроливным государством.

Турция действительно планомерно в течение нескольких десятилетий предпринимает меры по усилению контроля над судоходством в проливах, активно используя экологическую риторику, и пытается подменить международный режим регулирования нормами своего внутреннего законодательства. Однако Анкара не наделена полномочиями вводить какие-либо меры по регулированию без консультаций и согласования с другими участниками, в том числе в рамках Международной морской организации (ИМО). Россия, конечно эсе, крайне не заинтересована в уәсеточении прохода через проливы судов под российским флагом или жсе принадлежсащих российским судовладельцам.

Строительство Турцией канала, параллельного проливу Босфор, также никак не может привести к размыванию Конвенции Монтрѐ, но, тем не менее, способно несколько ухудшить ситуацию в области безопасности в черноморском регионе.

С одной стороны, Конвенция Монтрѐ действует как в отношении Босфора, соединяющего Чѐрное и Мраморное моря, так и пролива Дарданеллы - между Эгейским и Мраморным морями. Соответственно, путь к новому каналу из Эгейского моря в любом случае проходит через Дарданеллы, а это означает что все конвенционные ограничения на проход, прежде всего, военных кораблей нечерноморских стран будут оставаться в силе.

С другой стороны, пока теоретически, но с согласия турецких властей нахождение любого иностранного военного корабля водоизмещением не более 10 тыс. тонн в новом турецком 
канале, но не заходящего в акваторию Чѐрного моря, уже может быть не ограничено конвенционным лимитом в 21 сутки.

Несмотря на то, что к этим новым турецким каналам, как искусственным гидротехническим сооружениям, будет полностью применимо турецкое национальное законодательство, в международном морском праве уже давно сложилась норма обычного права: в каналах, используемых или же могущих использоваться для международного судоходства, должна соблюдаться свобода судоходства одинаково, как в отношении гражданских судов, так и военных кораблей для всех государствфлагов.

Однако между двумя проектируемыми каналами находится акватория Мраморного моря, воды которого являются по своему правовому статусу внутренними водами, находящимися под полным суверенитетом Турции. Соответственно, невозможность их не пересечения позволяет турецкому Правительству рассматривать эти каналы не как единую судоходную систему, а исключительно по отдельности, в т.ч. в части применения национального законодательства. Будет ли режсим судоходства через эти каналь более либерализован, в том числе и под давлением межоународного сообщества (в частности, США), или жсе Турции удастся отстоять, если не более жсесткий, то, как минимум, идентичный Конвенции Монтрё режсим применительно к ним - зависит от усилий Анкары.

В сентябре 2018 г. была анонсирована информация, что Правительство Турции приняло решение внести изменения в условия прохождения судов через свои проливы. В значительной части это касается ограничений на приближение к опорам мостов, уведомления за 10 дней о проходе судов длиной более 300 метров (в т.ч. применение обязательной лоцманской проводки), движения нефтетанкеров (и газовозов) только в дневное время.

Помимо этого, было заявлено, что турция будет приравнивать гражданские суда с военнылм грузами на бортук военнылм кораблям4. На практике это означает, что такие суда обязаны уведомлять по дипломатическим каналам о своем проходе за 8 дней (черноморские государства), или же за 15 дней (нечерноморские страны). Должна быть предоставлена информация о назначении, типе и числе судов, обозначена дата прохода в обоих

\footnotetext{
47 Турция изменила условия прохода судов через свои проливы / Black Sea News. 5.09.2018. URL: https://www.blackseanews.net/read/144108
} 
направлениях, а при проходе - данные о составе отряда, название судов и их количество.

Здесь возникает вопрос: будут ли меры по ограничению прохода военных кораблей нечерноморских государств также применяться к гражданским судам, перевозящим военные грузы? С одной стороны, Россия может быть заинтересована в таком нововведении, так как оно направлено на ограничение доставки военных грузов, прежде всего, со стороны США в порты черноморских государств (Украины, Грузии, Болгарии, Румынии).

С другой стороны, Россия сама осуществляет транзит военных грузов через проливы, прежде всего - в направлении Сирии. И такие ограничения будут, безусловно, затягивать процесс прохождения судов с российскими военными грузами.

Однако, с правовой точки зрения, отождествление гражданских судов, даже с военными грузами на борту, с военными кораблями по целому ряду критериев (наличие/отсутствие вооружения на борту) является выходящим далеко за рамки тех норм и положений, которые прописаны в Конвенции Монтрѐ. И вряд ли такие меры, даже если на них будет настаивать турецкая сторона, найдут одобрение других участников Конвенции.

Еще в 1978 г. между СССР и Турцией было заключено соглашение о разграничении континентального иельфа: дно Чѐрного моря было разделено между двумя странами по модифицированной срединной линии, каждая точка которой располагалась на равном удалении от советского и турецкого побережья. Затем, после того как Конвенцией 1982 г. был введѐн институт исключительной экономической зоны (ИЭЗ) и прибрежными государствами установлены такие зоны на Чѐрном море, СССР и Турция путем обмена нотами договорились о том, что линия границы континентального шельфа, установленная Соглашением 1978 г., является также и линией границы экономических зон между СССР и Турцией.

После распада СССР эта граница между двумя странами была поделена, соответственно, на украинско-турецкий; российскотурецкий и грузино-турецкий участки границы. Присоединение Крыма к России де-факто означает, что украинско-турецкого участка морской границы больше не существует, а есть достаточно протяженный участок российско-турецкой границы, основанный на предыдущих договоренностях 1978, 1986 и 1987 гг. 
Сложившаяся ситуация ведет к определенной правовой неясности: признает ли Турция суверенитет, суверенные права и юрисдикцию Российской Федерации в морских акваториях вокруг Крымa или же с еѐ стороны могут быть предприняты меры по опротестованию прав России в этих морских акваториях.

\section{Заключение}

Как и любая страна, Турция продолжает меняться, как по задумке политического руководства, так и вопреки ей. Ярые сторонники президента и не менее убежденные его противники не склонны к поиску компромиссов. Стремление к полноте власти встречает противодействие. Беспрецедентные президентские полномочия не обеспечивают экономического чуда и прочих важных для граждан достижений. Не только власть, но и оппозиция, ориентируясь на настроения избирателя, может предпочесть националистическую платформу, чреватую избыточным популизмом и нехваткой взвешенных рецептов развития.

Турция трудно встраивается в хитросплетения регионального баланса сил. Большинство региональных акторов одновременно заинтересованы в поддержании достаточно развитых отношений с этой страной и опасаются еѐ чрезмерного усиления. Турецким стратегам сложно сформировать прочные союзные отношения.

В непосредственной близости от Турции продолжается сирийский гражданский конфликт, меняющий расклады в болезненном для Турции курдском вопросе. Взаимодействие с Турцией переоценивают страны Запада, еще недавно вполне уверенные в общности подходов союзников по НАТО не только к оборонным вопросам, но и к демократическим стандартам и правам человека.

Хотя в ряде регионов между Россией и Турцией возникают противоречия, основа для взаимодействия двух стран достаточно 
прочна. Как Россия, так и Турция не заинтересованы в бесконтрольном усилении внерегиональных держав вблизи своих границ, они видят перспективу в развитии крупных инфраструктурных проектов, делают ставку на внутриполитическую стабильность и невмешательство во внутренние дела друг друга.

Тем не менее, принадлежность к разным «семьям» в вопросах международной безопасности может затруднить продвинутое сотрудничество на чувствительных направлениях. Несмотря на противоречия с Соединенными Штатами Турция сохраняет глубинную заинтересованность в членстве в НАТО, в то время как диалог России с Североатлантическим альянсом остается в тупике. 
Научное издание

Современная Турция: тренды развития

и значение для России

Под редакичей

Вартазаровой Людмиль Степановны

Кобринской Ирины Яковлевнь

Уткина Сергея Валентиновича

Научный доклад

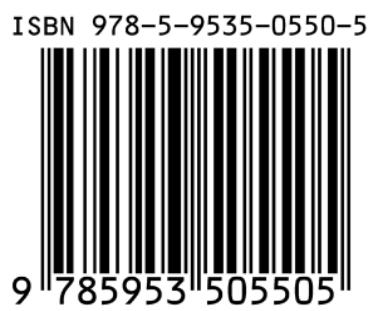

Подписано в печать 24.01.2019.

Формат $170 \times 240$ Печать офсетная.

Объем 6,75 п.л., 2,5 а.л. Тираж 100 экз. Заказ № 1/2019

Издательство ИМЭМО РАН

Адрес: 117997, Москва, Профсоюзная ул., 23 